\title{
Lateral slip rate of Alhama de Murcia fault (SE Iberian Peninsula) by a morphotectonic analysis: comparison with paleoseismological data
}

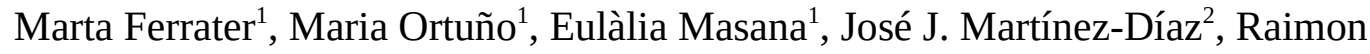
Pallàs $^{1}$, Hector Perea ${ }^{3}$, Stephane Baize ${ }^{4}$, Eduardo García-Meléndez ${ }^{5}$, Anna Echeverria ${ }^{1}$, Thomas Rockwell ${ }^{6}$, Warren D. Sharp ${ }^{7}$, Ramon Arrowsmith ${ }^{8}$

(1) RISKNAT Group. GEOMODELS. Departament de Geodinàmica i Geofísica, Facultat de Geologia, Universitat de Barcelona, c/ Martí i Franquès, s/n, 08028 Barcelona, Spain. Email: marta.ferrater@ub.edu

(2) Departamento de Geodinamica, Universidad Complutense, Instituto de Geociencias IGEO (UCM, CSIC), 28040 Madrid, Spain

(3) Barcelona Center for Subsurface Imaging (B-CSI), Departament de Geociències Marines - Institut de Ciències del Mar - CSIC, 08003 Barcelona, Spain

(4) Institut de Radioprotection et Sûreté Nucléaire - Seismic Hazard Division (BERSSIN), BP 17, 92262 Fontenay-aux-Roses, France

(5) Área de Geodinámica Externa, Facultad de CC. Ambientales, Universidad de León, Campus de Vegazana s/n 24071 León, Spain

(6) Department of Geological Sciences, San Diego State University, San Diego, CA 92182, USA

(7) Berkeley Geochronology Center, Berkeley, CA 94709, USA

(8) School of Earth and Space Exploration, Arizona State University, Tempe, AZ 85287-6004, USA

Quaternary International (Special Issue)

Keywords: tectonic geomorphology; strike-slip fault; Eastern Betics Shear Zone; offset channels

To define the seismic potential of the left-lateral strike-slip Alhama de Murcia fault (SE Iberian Peninsula), we calculated its slip rate by measuring offset linear features of known age using a morphotectonic analysis. The Lorca-Totana section of the fault yielded a minimum slip rate of $1.0 \pm 0.2 \mathrm{~mm} / \mathrm{a}$ for the past $30 \mathrm{ka}$, based on a channel whose age is estimated by OSL technique. The minimum left-lateral slip rate of the Goñar-Lorca section is 1.6-1.7 mm/a for the past $200 \mathrm{ka}$, based on eight offset surface channels, previously mapped alluvial fans dated by $T L$, and by new $U$-series dating of pedogenic carbonate. The U-series technique was used here for first time in the Iberian Peninsula to date small amounts (mg) of pedogenic carbonate. According to the newly estimated slip rate values, the Alhama de Murcia fault is one of the most active faults in the Eastern Betics Shear Zone. These values are larger and have fewer uncertainties in 
comparison with previous slip rates estimations. In the Lorca-Totana section, the new lateral slip rate is compared with a slip rate calculated by means of a paleoseismic study showing good agreement between the values obtained with the two approaches. We encourage the combination of paleoseismology and morphotectonic analysis to obtain reliable slip rates for faults with scarce evidence of late Holocene slip.

\section{Introduction}

The slip rate is an essential parameter to characterize the seismic potential of active faults. In strike-slip faults, the estimation of lateral slip rate is based on reconstructing the offset of linear features of known age. Offsets can be determined through morphotectonic analysis of superficial features, such as offset channels (Rockwell et al., 1990; Van der Woerd et al., 2002; Fu et al., 2005; Ferry et al., 2007; Frankel et al., 2007; Chevalier et al., 2012; Salisbury et al., 2012; Campbell et al., 2013, among others), or can be measured from buried linear features, such as paleochannels, revealed by paleoseismological trenching (Wesnousky et al., 1991; Lindvall and Rockwell, 1995; Hall et al., 1999; Marco et al., 2005; Liu-Zeng et al., 2006; Rittase et al., 2014). Providing that accurate geochronological control is available, either morphotectonic analysis or paleoseismological trenching usually yield reliable slip rates in the case of faults moving at $>1 \mathrm{~cm} / \mathrm{a}$, allowing for a better estimation of seismic hazard. On the other hand, the studies attempting the quantification of lateral slip rates in more slowly tectonic contexts tend to integrate different types of data and methodologies. For instance, Vanneste et al. (2006) combined geomorphological, geophysical and trenching analyses to study a normal fault with a dextral component in Bulgaria. These authors obtained a $0.037 \pm 0.017 \mathrm{~mm} / \mathrm{yr}$ of vertical slip rate analyzing a Plio-Pleistocene scarp and a Holocene fault slip rate of $0.22 \pm 0.12 \mathrm{~mm} / \mathrm{yr}$ calculated from paleoseismological trenches. Another example is Moreno (2011) that combined geodetic, paleoseismic and geomorphic information onshore and offshore to calculate $1.31 \mathrm{~mm} / \mathrm{yr}$ of lateral slip rate along the seismically silent Carboneras fault in the Eastern Betics Shear Zone (EBSZ; Fig. 1).

The slip rate values of the Alhama de Murcia fault (AMF; SE Iberian Peninsula; Fig. 1) have been estimated, in most cases associated with large uncertainties, by means of morphotectonic and paleoseismic studies. The first lateral slip rate based on offset channels on surface was done by Martínez-Díaz (1998). He estimated a $0.6 \mathrm{~mm} / \mathrm{yr}$ 
lateral long-term (1 Ma) slip rate for the Goñar-Lorca section based on one channel offset more than $600 \mathrm{~m}$. Later, Martínez-Díaz et al. (2003) obtained a $0.21 \mathrm{~mm} / \mathrm{yr}$ lateral slip rate for Lorca - Totana fault section for the past 130 ka without specifying the uncertainty associated with the calculation. At the southern termination of the fault, Ortuño et al. (2012) identify five offset channels that yield a total lateral slip rate of 0.95 - $1.37 \mathrm{~mm} / \mathrm{yr}$ for the past 125-1600 ka. Ferrater et al. (2015) mapped 138 offset features along the fault, but these offsets were not used to calculate a lateral slip rate. On the other hand, offset buried channels have also yield slip rate values by a threedimensional paleoseismic study (Ferrater et al., 2016). This study calculates net, lateral and vertical slip rates of $0.9 \pm 0.1 \mathrm{~mm} / \mathrm{yr}, 0.9 \pm 0.1 \mathrm{~mm} / \mathrm{yr}$ and $0.1 \pm 0.0 \mathrm{~mm} / \mathrm{yr}$ (past 20 ka), respectively, for one strand of the fault based on the 3D offset of a buried paleochannel. These values are significantly larger (1.5 to 15 times larger) than the maximum values previously obtained with a classical paleoseismic analysis carried out by Martínez-Díaz et al. (2003) and Masana et al. (2004); and are characterized by using the same criteria for calculating all the components of the slip rate. Martínez-Díaz et al. (2003) and Masana et al. (2004) suggested a vertical slip rate of $0.04-0.35 \mathrm{~mm} / \mathrm{yr}$ at the El Saltador paleoseismic site in the Lorca-Totana section (Fig. 2) and, based on the orientation of some slickensides, estimated a $0.07-0.66 \mathrm{~mm} / \mathrm{yr}$ net slip rate and 0.06 $0.53 \mathrm{~mm} / \mathrm{yr}$ lateral slip rate (for the past $30 \mathrm{ka}$ ). These values should be considered with caution as they were based on an estimation of the vertical offset based on the morphology of the alluvial fan (microtopographic profiles) assuming no strong influence of the lateral offset of its conic shape or local topographic features as channel grooves. Also by means of paleoseismic trenches, Ortuño et al. (2012) estimated a vertical slip rate of $0.16-0.22 \mathrm{~mm} / \mathrm{yr}$ at the southern termination of the fault (at the vicinity of Goñar; Fig. 1).

The aim of this paper is to calculate the lateral slip rate of the Alhama de Murcia fault by means of a morphotectonic analysis and to reduce the present-day uncertainties associated to it. The used offset channels are the ones identified, characterized and measured by Ferrater et al. (2015) and the age constraints for these channels are: a) the luminescence-based chronological dataset of Ortuño et al. (2012), and b) new U-series dates on pedogenic carbonate. This last method is used here for the first time in the Iberian Peninsula to date small amounts (milligrams) of pedogenic carbonate. The new slip rates support and complement those obtained from paleoseismic studies in the same 
fault, and the advantages and disadvantages of each approach are debated. Finally, we discuss the regional implications of the newly established slip rate for the AMF.

\section{Geological setting}

The AMF is located within the Eastern Betics, which are the northern branch of the Gibraltar arc and which are divided into the internal (Alpujarride, Malaguide and Nevadofilabride) and the external units (Fig. 1). The Gibraltar arc was formed during the Miocene as a consequence of the alpine collision between the Eurasian and the African plates. In the SE Betics, two extensional phases occurred between Burdigalian and Tortonian (Martínez-Martínez and Azañón, 1997; Rodríguez-Fernández et al., 2012). The neotectonic compressive period initiated $~ 9$ Ma ago with a shortening oriented NNW-SSE. The interplay between the Tortonian extension and a later phase of inversion (commencing in the latest Tortonian) resulted in a basin and range structure over the eastern Betics (Montenat et al., 1990; Meijninger and Vissers, 2006) giving rise to several Neogene to Quaternary basins. Present-day the convergence between the Eurasian and the African plates occurs at a rate of 4-6 mm/yr with a NW-SE orientation (Serpelloni et al., 2007; Argus et al., 2011; Nocquet, 2012). The Eastern Betics Shear Zone (EBSZ; Fig. 1B; De Larouziére et al., 1988) is a large shear fault system associated with this convergence that could be absorbing up to 31 \% (Masana et al., 2004) of the shortening between the two plates. The faults forming the EBSZ are (from south to north): the Carboneras, the Palomares, the Alhama de Murcia, the Carrascoy and the Bajo Segura faults (Fig. 1B).

The Alhama de Murcia fault is an $87 \mathrm{~km}$ N45E - N65E left-lateral strike-slip fault dipping to the northwest with a minor reverse component (Bousquet, 1979; MartínezDíaz, 1998). It was formed during the tectonic inversion, probably reactivating a Tortonian extensional fault, initiating its strike-slip activity in the Pliocene or Quaternary (Bousquet, 1979; Meijninger and Vissers, 2006). The fault separates three mountain ranges (the Espuña, the La Tercia and the Las Estancias ranges) from the Guadalentín and Huercal-Overa depressions. The fault zone cuts: a) the Alpujárride and the Maláguide complexes of the Betic basement in the Las Estancias and the La Tercia ranges, b) late Miocene formations and c) the continental Quaternary deposits that infill the Guadalentín and Huercal-Overa depressions (Fig. 1C; Bousquet, 1979). The first geodetic measurements based on GPS derived station velocities across the region have 
recently yielded a high horizontal slip rate estimation of $1.5 \pm 0.3 \mathrm{~mm} / \mathrm{yr}$ that includes the AMF and the Palomares fault (Fig. 1B; Echeverria et al., 2013).

Several damaging historical earthquakes of intensity VII-VIII EMS have been produced by the AMF (IGN, 2016). The largest instrumental earthquake was recorded in Lorca on May 11th, 2011, with a moment magnitude (Mw) 5.2 and a maximum intensity VII (EMS), and was preceded by a Mw 4.5 foreshock (Fig. 1C). The focal mechanisms of the two events show oblique left lateral-reverse faulting (Fig. 1C; Lopez-Comino et al., 2012; Martínez-Díaz et al., 2012a) and no surface rupture in this seismic sequence has been identified.

Silva (1994) and Martínez-Díaz et al. (2012b) divided the AMF in four sections according to their orientation, geometry of the fault zone, geomorphic expression and seismicity. From south to north, these are (Fig. 1C): 1) Góñar-Lorca (NNE-SSW), characterized by a horse tail termination to the south that merges into a narrow fault zone to the north, by the presence of the Las Estancias range in the hanging wall and moderate seismicity; 2) Lorca-Totana (NE-SW), where the fault turns into a N60E strike, splits into three main sub-parallel fault traces, bounding the south of the La Tercia range; 3) Totana-Alhama de Murcia (NNE-SSW), where the fault still exhibits several strands, SE of the Espuña range; and 4) Alhama de Murcia-Alcantarilla (NNESSW), where the geomorphic expression of the fault is diffuse, probably because deformation is transferred to the Carrascoy fault to the NE (Fig. 1B; Martínez-Díaz et al., 2012b). 


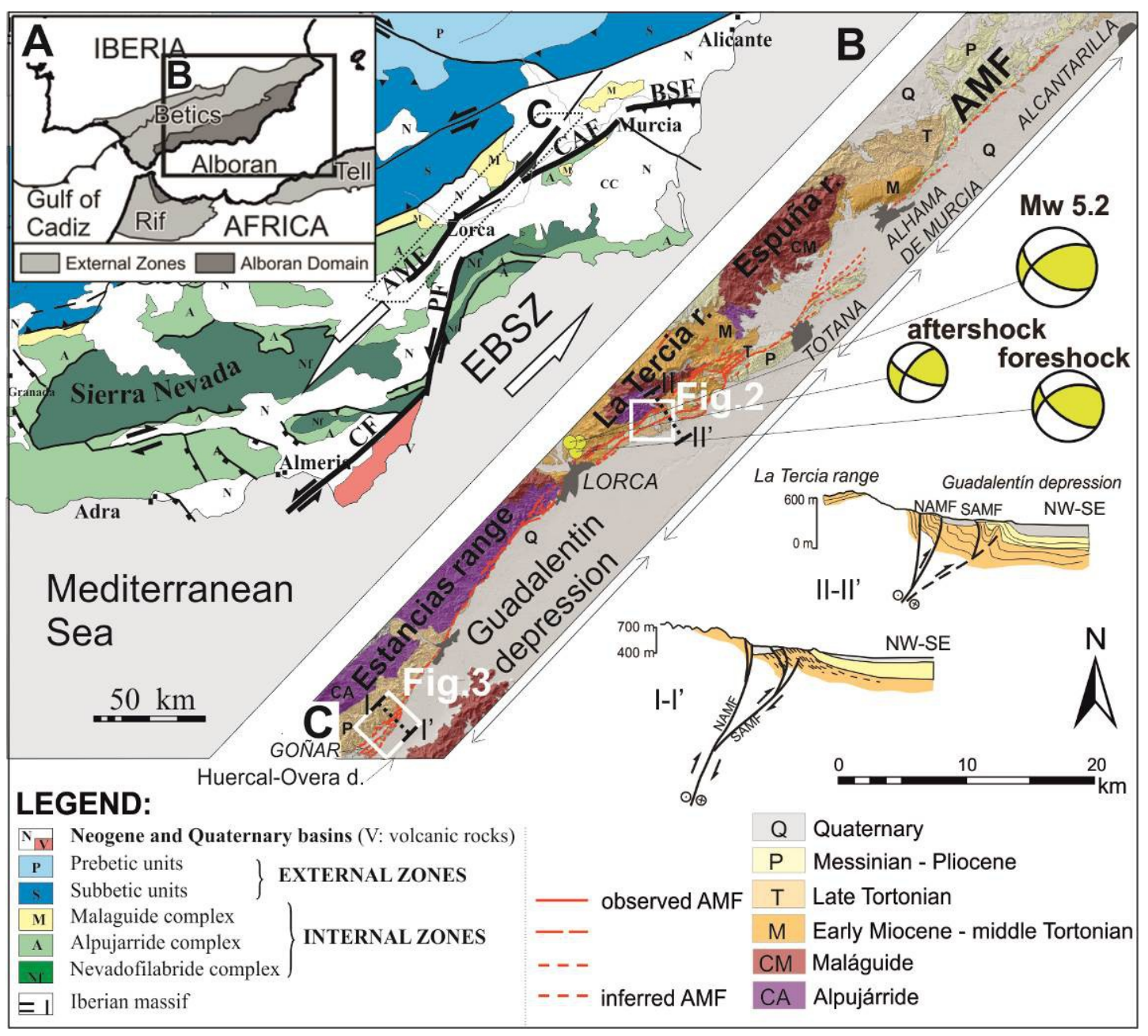

Figure 1. A) Gibraltar arc in the SE Iberian Peninsula; B) geological map of the SE Iberian Peninsula, the Alhama de Murcia fault is part of the Eastern Betics Shear Zone (EBSZ faults in bold line: CF, Carboneras fault; PF, Palomares fault; CAF, Carrascoy fault; BSF, Bajo Segura fault); C) geological map of the AMF where fault sections, the affected units and the seismic events of the $11^{\text {th }}$ of May 2011 (Martín et al., 2015) are shown. Geological profiles from Martínez-Díaz et al. (2012) showing the depth structure of the AMF.

The youngest deposits along the AMF study area are mostly proximal facies of PlioQuaternary alluvial fans draining the main ranges in the area towards the Guadalentin (central parts) and Huercal-Overa (southern parts) depressions. Several studies have focused on the cartography of the alluvial fans based on relative criteria, such as spatial relationships and entrenchment (Silva et al., 1992; Martínez-Díaz et al., 2003; Soler et al., 2003; Masana et al., 2004; Silva et al., 2008; Ortuño et al., 2012; Table 1). Moreover, Ortuño et al. (2012) classified the alluvial fans in the southernmost termination of the fault into seven alluvial fan generations (G0 to G6) based on 24 numerical ages obtained with thermoluminescence (TL) and elevated-temperature 
infared stimulated luminescence (pIRIR) of 11 units exposed in paleoseismological trenches and natural outcrops.

\begin{tabular}{|c|c|c|c|c|c|c|c|}
\hline $\begin{array}{l}\text { Study } \\
\text { reference }\end{array}$ & $\begin{array}{l}\text { Martínez-Díaz et } \\
\text { al., 2001; Masana } \\
\text { et al., } 2004\end{array}$ & \multicolumn{2}{|c|}{$\begin{array}{l}\text { Martínez-Díaz et al., } \\
2003\end{array}$} & \multicolumn{2}{|c|}{ Ortuño et al., 2012} & $\begin{array}{l}\text { Silva et al., } \\
1992\end{array}$ & $\begin{array}{l}\text { Soler } \\
\text { et al., } \\
2003\end{array}$ \\
\hline Study area & Lorca-Totana & \multicolumn{2}{|c|}{ Lorca-Totana } & \multicolumn{2}{|l|}{ Goñar } & $\mathrm{AMF}$ & $\mathrm{AMF}$ \\
\hline \multirow{4}{*}{ 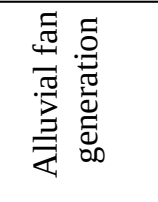 } & & $\mathrm{F}$ & Hol.-L. Pleist & G0 & $\mathrm{Hol}$ & 3r phase & G7 \\
\hline & Young & $\mathrm{E}$ & Hol.-L. Pleist & G1-G2 & Hol.-L. Pleist & 2nd phase & G6 \\
\hline & Intermediate & $\mathrm{D}-\mathrm{C}$ & L.-M. Pleist & G3-G4 & L.-M. Pleist & 1st phase & G4 \\
\hline & Old & C-B & M. Pleist-Plio & G5, G6 & M. Pleist & 1st phase & G3 \\
\hline
\end{tabular}

Table 1. Correspondence between alluvial fan generations described by previous studies based on relative criteria, such as spatial relationships and entrenchment (Silva et al., 1992; Martínez-Díaz et al., 2001; Martínez-Díaz et al., 2003; Soler et al., 2003; Masana et al., 2004; Ortuño et al., 2012). Hol., Holocene; L., Late; M., Middle; Pleist., Pleistocene; Plio., Pliocene.

\section{Methodology}

The morphotectonic studies that aim to calculate the lateral slip rate of an active fault are based on the offset of a linear feature whose age is known. Generally these linear features are terrace risers or channels. The maximum age of a channel is the age of the surface where it is entrenched on and it corresponds to the time of alluvial fan abandonment (e.g. Fu et al., 2005; Fletcher et al., 2011; Chevalier et al., 2012; Campbell et al., 2013). We assumed that each channel was entrenched an undetermined time after the abandonment of the alluvial deposition, which may be different for all the channels on the same surface, explaining why channels in the same surface may yield different amounts of offset. The amount of offset and its age allow estimating the minimum lateral slip rate of a given fault. In the AMF case, the slip rate was calculated using Zechar and Frankel (2009) functions for the Goñar-Lorca and the Lorca-Totana sections. These functions were designed to be applied in active tectonics studies and allow obtaining the uncertainty distribution of the probability of the displacement, of the age and of the slip rate and their statistical values, such as the mean, the mode and the median (e.g. Fletcher et al., 2011).

\subsection{Offset measurement}

The 138 offset measurements that Ferrater et al. (2015) obtained analyzing a $0.5 \times 0.5 \mathrm{~m}$ pixel size Digital Elevation Model (DEM) created from a point cloud acquired in 2013 
by airborne light detection and ranging (lidar) and orthophotographs created from 1956 aerial photographs (1:33,000 scale) were reviewed in this paper. To measure the offset, the estimation of the pre-deformation morphology and the identification of the piercing points are required. The displacement measured is the sum of the initial deflection, caused for instance by a pre-existing topographic feature, and the tectonic offset. Here we assumed that the channels were entrenched with no initial deflection, as present-day analogues suggest (Ferrater et al., 2016).

The piercing points are obtained by means of projecting the channel tendency into the fault, and more than one pair of piercing points per channel may be identified. For instance, Gold et al. (2011) consider the near and full channel projections of either the margins or the thalweg. The combination they do of all piercing point pairs yield the mean, the maximum and the minimum offset values. Ferrater et al. (2015) followed this criterion, and computed the mean and mean standard deviation for all the combinations between the near and full projections of the identified channels offset by the AMF. In addition, these authors assigned a subjective and objective quality between 0 and 1 to each channel offset (being 0 the lowest score and 1 the highest score). These quality values are used here when considering the reliability of the offset channel before calculating the slip rate.

\section{2. $\quad$ Age constraints of Quaternary sediments}

The age of an offset feature is an essential parameter for slip rate calculation being largely responsible for the high uncertainty values in the final result. The upper limit of the radiocarbon dating method ( $\sim 55 \mathrm{ka}$; Libby, 1955) does not allow its application within most of the Late Pleistocene, a key interval for characterizing faults with slip rates under $1 \mathrm{~cm} / \mathrm{yr}$. Moreover, in arid regions, organic materials suitable for radiocarbon dating may be thinly or discontinuously distributed and poorly preserved. For this reason, previous studies in the AMF area have dated Quaternary units combining several dating techniques, such as radiocarbon $\left({ }^{14} \mathrm{C}\right.$; Martínez-Díaz et al., 2003, Masana et al., 2004; Silva et al., 2008), thermoluminescence (TL; Martínez-Díaz et al., 2003, Masana et al., 2004; Ortuño et al., 2012), U-series dating applied to calcrete (Masana et al., 2004) and cosmonuclide $\left({ }^{10} \mathrm{Be}\right.$ and ${ }^{26} \mathrm{Al}$; Rodés et al., 2011) techniques. Here we provide new numerical ages by applying U-series to date pedogenic carbonate and we combine them with previous data. The use of more than one method extends the 
range of materials that may be dated and can enhance the reliability of the resulting ages.

\subsubsection{U-series of pedogenic carbonate}

Pedogenic carbonate accumulates in the soil profile in the B or $\mathrm{K}$ horizons in arid and semiarid regions (Gile et al., 1966; Machette, 1985; Birkland, 1999; Schaetzl and Anderson, 2005). In coarse alluvium, carbonate initially forms thin coatings at the bottom of the clasts (Arkley, 1963; Gile et al., 1966; Machette, 1985). The $\mathrm{CaCO}_{3}$ may come from dissolution of carbonate bearing rocks within the soil profile, from eolian dust accumulated on the surface (e.g., Amundson et al. 1994; Cerling, 1999; Capo and Chadwick, 1999). Soil carbonate commonly contains a few ppm of uranium due to incorporation of uranium present in soil waters; however, thorium, which is relatively insoluble in typical soil waters, is extremely low in pure authigenic carbonate (e.g., Sharp et al. 2003).

U-series dating can be applied to clast-coatings younger than 0.5 Myr made of dense, pure and laminated carbonate (e.g., Ku et al., 1979; Ludwig and Paces, 2002; Sharp et al., 2003). U-series ages of pedogenic carbonate yield reliable dates for soil formation and represent the minimum ages for the host alluvium because a time after its deposition must elapse before dateable amounts of dense carbonate accumulate. The time lag between alluvial deposition and accumulation of dateable carbonate may vary from a few hundred to a few thousand years depending on the rate of carbonate accumulation in the soil and sampling techniques (e.g., Sharp et al., 2003; Blisniuk et al., 2012). Pedogenic carbonate dating has been successfully applied to alluvium as young as the mid-Holocene in the Anza Borrego Desert of southern California (Blisniuk et al., 2012).

Clasts containing thin coatings of carbonate were sampled in the B horizon of the soil. We dated eight soil profiles along the AMF: three of them in the Lorca-Totana fault section (Fig. 2) and four in the Goñar-Lorca fault section (Fig. 3). Preparation procedures and isotopic measurements were done in the Berkeley Geochronology Center and were similar to those described by Gold et al. (2015). First the clasts were cleaned using a soft nylon brush. The carbonate coatings were separated from the clasts and inspected under a microscope. Then, external contaminants in the coatings were removed in an ultrasonic bath. The carbonate was dissolved in $\mathrm{HNO}_{3}$ and spiked with a 
mixture of ${ }^{229} \mathrm{Th},{ }^{233} \mathrm{U}$ and ${ }^{236} \mathrm{U}$. Finally, the samples were analyzed using a Termo Neptune multicollector inductively coupled plasma-mass spectrometry (MC-ICP-MS).
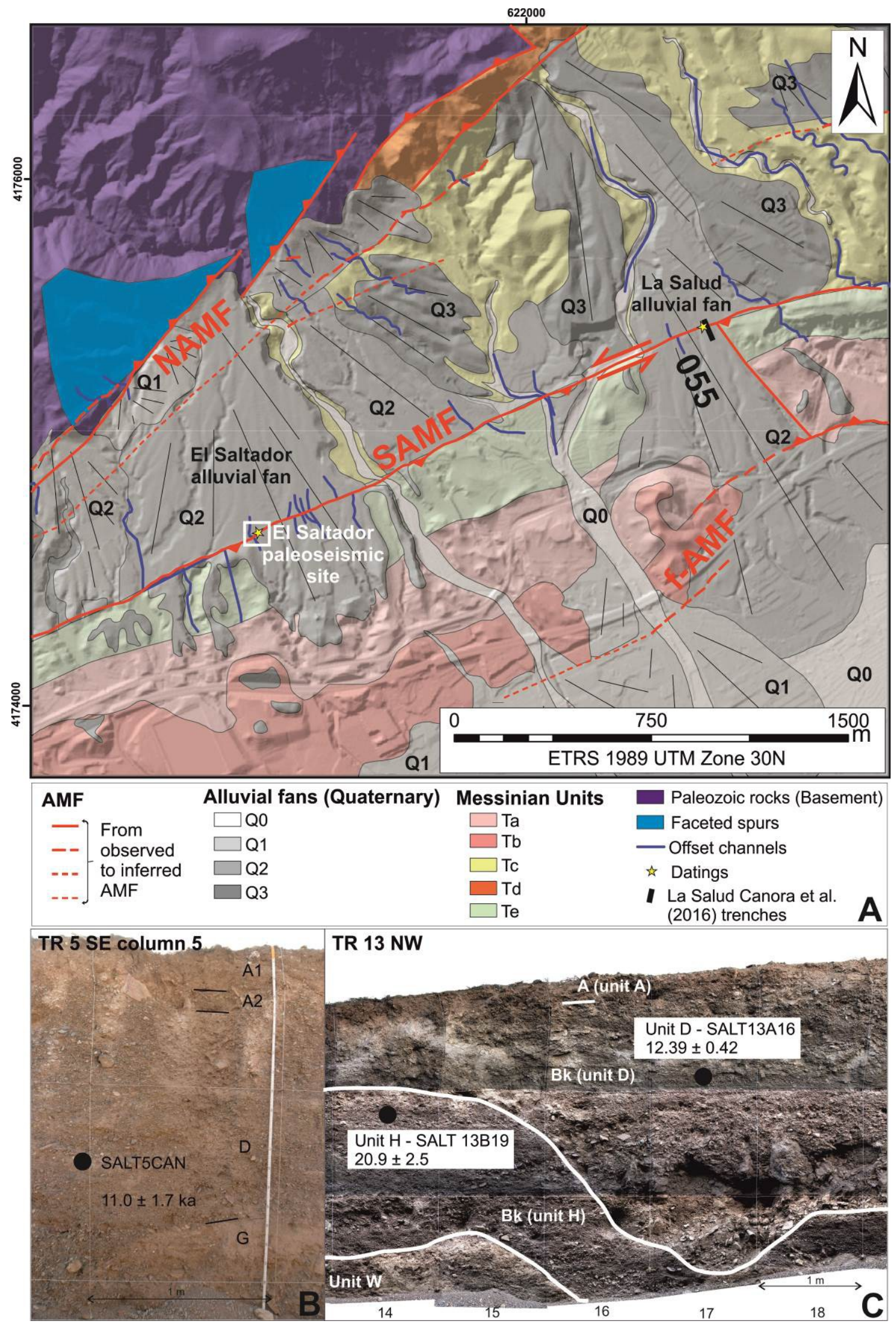
Figure 2. A) Geological map (position in Fig. 1) of the Lorca-Totana section modified from Martínez-Díaz et al. (2003); white square highlights the trenching site; the number 055 refers to an offset channel in surface. B) Soil profile associated with the SALT5CAN pedogenic carbonate sample, described in the TR5 of the El Saltador paleoseismological site. C) Soil profile associated with samples SALT13A16 and SALT13B19, described in the TR13 of the El Saltador paleoseismological site. 

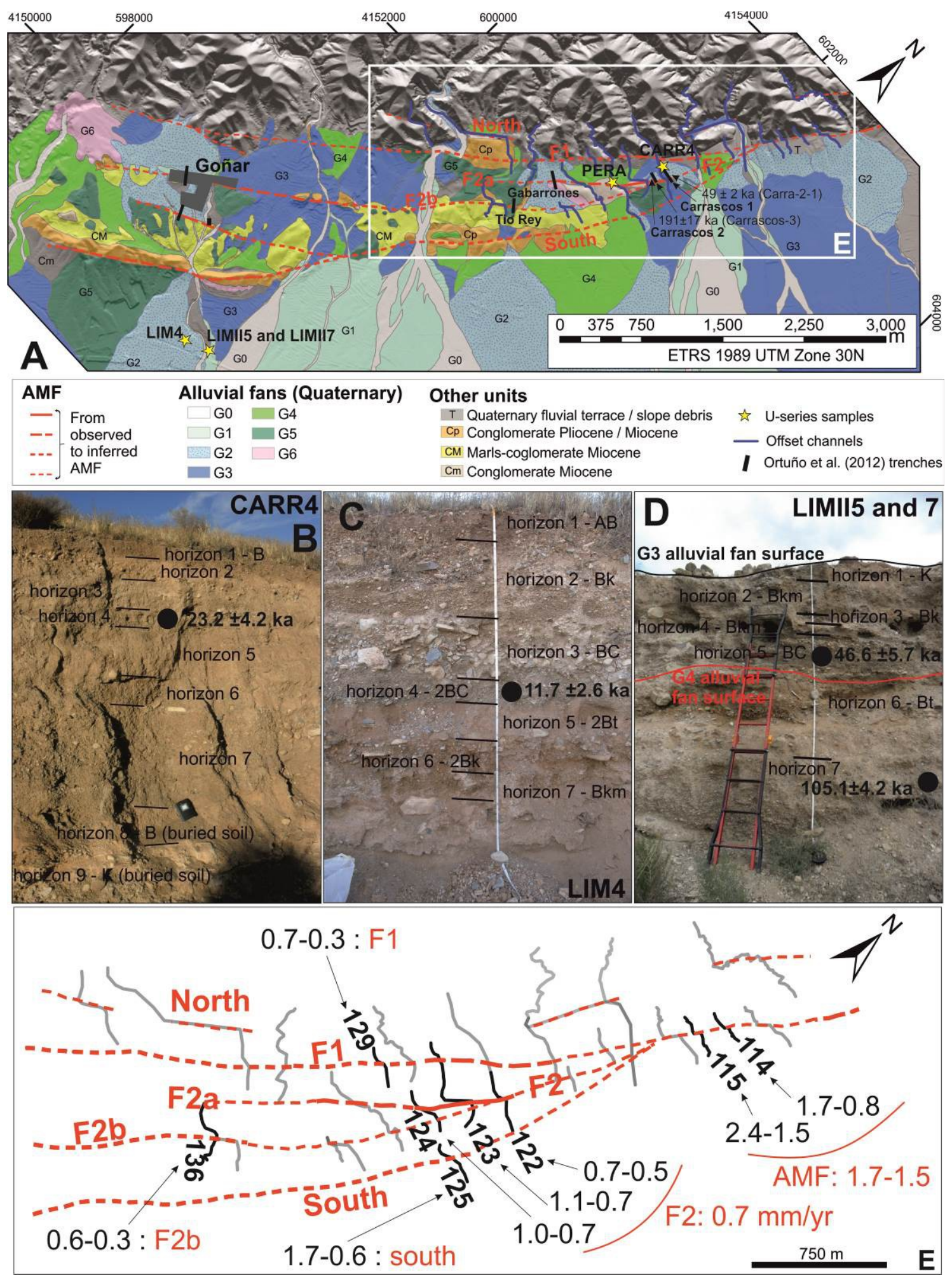

Figure 3. A) Geological map (position in Fig. 1) of the southernmost termination of the fault at the vicinity of Goñar modified from Ortuño et al. (2012) with the position of the edafic profiles CARR4, PERA, LIM4, LIMII5 and LIMII7 where the pedogenic carbonate was sampled is highlighted, and with the location of the selected best quality offsets used to calculate the slip rates. B) Soil profile associated with the CARR4 pedogenic carbonate sample. C) Soil profile associated with the LIM4 pedogenic carbonate sample. D) Soil profile associated with the LIMII5 and LIMII7 pedogenic 
carbonate samples. E) Summary of the slip rates obtained using the selected offsets. The offset measurements (indicated in the maps with three digit numbers next to a channel) are listed in Table 4.

To estimate the minimum age of the host alluvium, we calculated the weighted mean age of the three oldest U-series dates reproducible within analytical errors. This protocol is employed to help exclude biased ages-for example, those produced if the U-Th system fails to remain closed, or a clast-coating inherited from an older landform is dated-since such anomalous ages are unlikely to be reproducible. We reported the resulting U-series ages at the $1 \sigma$ confidence level (Table 2 and Table S1 of the Supplementary material).

\begin{tabular}{|c|c|c|c|}
\hline Sample Name & Fault section & Preferred U-Th Age (ka, \pm ka) & Probability \\
\hline SALT13A16 & \multirow{3}{*}{ Lorca-Totana } & $12.39 \pm 0.42$ & 0.88 \\
\hline SALT13B19 & & $20.9 \pm 2.5$ & 0.62 \\
\hline SALT5CAN & & $11.0 \pm 1.7$ & 0.97 \\
\hline CARR4 & \multirow{5}{*}{ Goñar-Lorca } & $23.2 \pm 4.2$ & 0.95 \\
\hline LiM4 & & $11.7 \pm 2.6$ & 0.84 \\
\hline LIMII5 & & $46.6 \pm 5.7$ & 0.75 \\
\hline PERA & & $23.8 \pm 3.2$ & 0.76 \\
\hline LIM II7 & & $105.1 \pm 4.2$ & 0.12 \\
\hline
\end{tabular}

Table 2. Weighted mean ages for pedogenic carbonate samples. The mean is calculated using the three oldest samples of Table S1 (Supplementary material). The right coherence indicates the probability that the observed scatter is due to analytical errors.

\section{Estimating the fault slip rate by morphotectonic analysis}

The slip rate estimation was done for two sections: Goñar-Lorca and Lorca-Totana sections (Fig.s 2 and 3). The selected offset channels used for this estimation have: a) moderate to high quality score, and b) available age control.

\subsection{Góñar-Lorca section}

This section includes the southern horse-tail termination of the fault (Fig. 3), which is made up of: 1) two boundary faults, the northern and the southern Alhama de Murcia fault, and 2) several internal structures, known as the Goñar faults (Ortuño et al., 2012). These faults affects Miocene and Quaternary sediments. Here, we modified slightly the nomenclature of the Goñar faults in order to simplify their references in the text when calculating their slip rates (Fig. 3).

We selected eight offset channels at the southernmost termination of the section: 114115, 122-125, 129 and 136 (Fig. 3 and Figs. S1-S8). Channels 114-115 are affected by 
fault strand F1 and are entrenched into slope debris deposits overlying the G2 alluvial fan (21-25 ka). Channel 114 (Fig. S1; Fig. 4) is still active; its sinuosity is low and the orientation of the two channel sections is very similar, thus being a reliable marker (Ferrater et al., 2015). The offset of this channel was measured remotely and in the field (Fig. 4) resulting in larger uncertainties in the second method. Channel 115 has been modified by human action (Fig. S2), but the incision displayed in the old ortophotographs is similar for the two sections of the channel, yielding good quality ratings (Ferrater et al., 2015). Channels 122-124 are affected by fault strand F2. They are entrenched into alluvial fans of different generations: channel 122 is on the G3 alluvial fan (41-61 ka), channel 123 is on the G5 alluvial fan (145-208 ka); and 124 is entrenched into the G4 alluvial fan (125-149 ka). Channel 125 is on the G4 alluvial fan and is the only one identified for the southernmost fault strand. The incision of channel 129 (Fig. S7) into the Quaternary sediments is shallow. These sediments onlap the G4 alluvial fan, and thus, we considered the maximum age of the channel to be the age of the alluvial fan generation G4. Finally, channel 136 crosses the fault F2b. This fault is associated with significant relief and, thus, with an uncertain large vertical component, suggesting that erosion may play a significant role in entrenchment. Alternatively, uplift may also have influenced an initial diverted entrenchment of this channel due to the differences in erosion resistance. The upper part of the channel is entrenched into the G5 alluvial fan.
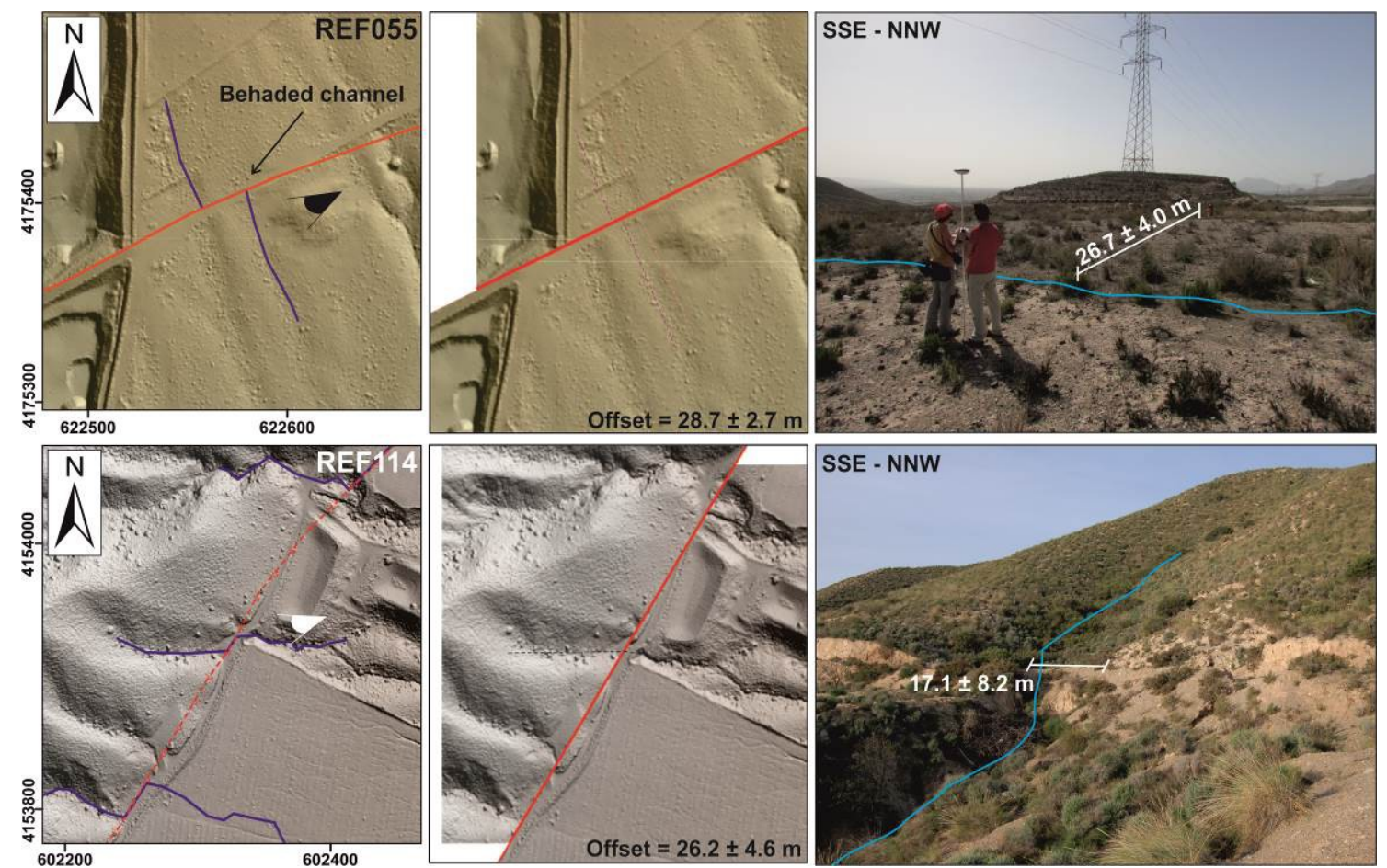
Figure 4. Examples of offsets measured remotely and with larger uncertainties in the field. Location of the offsets in Fig. 2 (055) and in Fig. 3 (114). The eye symbol indicates the perspective of the pictures shown on the right. The interpretation of all the offsets used to calculate the slip rate is in the Supplementary material (Figs. S1-S8).

\subsubsection{Age control}

To constrain the age of the alluvial fans where the offset channels are entrenched we used 1) the age estimates and the alluvial fan generations (G0-G6) from Ortuño et al. (2012), and 2) the new dates obtained from U-series of pedogenic carbonate (Table 3). Most of the ages obtained by thermoluminescence (TL) and elevated-temperature Infrared Stimulated Luminescence (pIRIR) from trenching sites provided by Ortuño et al. (2012) are from buried and/or local units and do not give the age of alluvial fan abandonment, but the age of an alluvial unit within the alluvial fan. Consequently, their use gives the maximum ages, i.e. minimum slip rates. On the other hand, U-series dates indicate the minimum age of the host alluvium. The new numerical ages (CARR4, LIM4, LIMII5, LIMII7 and PERA; Fig. 3) belong to different alluvial fan generations described by Ortuño et al. (2012): CARR4 and LIM4 correspond to the G2 generation, LIMII5 to G3, and PERA and LIMII7 to the G4 alluvial fan generation (Fig. 3). Sample LIMII7 belongs to a buried paleosoil developed on top of the G4 generation alluvial fan. In general, the new U-series ages in the Goñar-Lorca section corroborates the age of the generations proposed by Ortuño et al. (2012) (Table 3). For generation G2, there is an agreement between the values of samples Gaba-3 and CARR4 (both samples from unit D1 in the trenches studied by Ortuño et al., 2012). On the other hand, although sample LIM4 is much younger than the others, its age does not affect the G2 age, as it is a minimum value for the host unit. Samples for generation G3 are consistent, including LIMII5, slightly younger but in the same range. Samples PERA and LIMII7 are younger (PERA is much younger) than the other samples belonging to this generation. Sample LIMII7 indicates the minimum age for the alluvial fan, but differences between sample PERA and the preferred age for generation G4 may be due to the fact that the soil sample was rejuvenated, or that it corresponded to a small younger terrace or unit.

Where age control is available, we used the age of the alluvial fan unit where the channel is located to estimate the age of the channel. Otherwise, we utilized the preferred age of the alluvial fan generation considered in Table 3 or the spatially 
closest numerical dates. The maximum ages of the fan surface where offsets 122 and 123 are measured were obtained based on age estimates from trenches due to the proximity of the identified channels and the trenches. The maximum age of the alluvial fan with the offset channel 136 was estimated using the age of sample Carrascos-3 which is the best constrained age of the generation G5 top surface. For the remainder of the selected offsets, we used the preferred age of the alluvial generation (by correlation) to calculate the minimum slip rate.

\begin{tabular}{|c|c|c|c|c|}
\hline Sample & Age (ka) & Method & $\begin{array}{l}\text { Depositional phase } \\
\text { (Ortuño et al., 2012) }\end{array}$ & $\begin{array}{l}\text { Preferred age for the } \\
\text { alluvial fan generation }(\mathrm{ka})\end{array}$ \\
\hline Gaba-3 & $23 \pm 2$ & pIRIR & $\mathrm{G} 2$ & \multirow{3}{*}{ 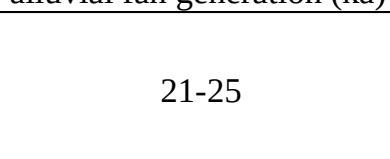 } \\
\hline CARR4 & $23.2 \pm 4.2$ & U-series & G2 & \\
\hline LIM4 & $11.7 \pm 2.6$ & U-series & G2 & \\
\hline Carr-1-2 & $52.4+7.9 /-6.4$ & TL & G3 & \multirow{7}{*}{$41-61$} \\
\hline Carra-2-1 & $49 \pm 2$ & pIRIR & G3 & \\
\hline Berm-1 & $46.3+6.1 /-5.1$ & TL & G3 & \\
\hline LIMII5 & $46.6 \pm 5.7$ & U-series & G3 & \\
\hline Era-4 & $58 \pm 3$ & pIRIR & G3 & \\
\hline Sard-2 & $61.9+15 /-11.2$ & $\mathrm{TL}$ & G3 & \\
\hline Sard-4 & $61 \pm 2$ & pIRIR & G3 & \\
\hline Carr-1 & $126+0 /-23$ & TL & G3-G4 & \multirow{6}{*}{$90-147$} \\
\hline Gaba-2 & $108 \pm 8$ & pIRIR & G3-G4 & \\
\hline Gaba-1 & $111+36 /-21$ & TL & G3-G4 & \\
\hline Era-3 & $107 \pm 5$ & pIRIR & G3-G4 & \\
\hline Sard-1 & $120+39 /-21$ & TL & G3-G4 & \\
\hline Era- & $110+33 /-19$ & TL & G3-G4 & \\
\hline PERA & $23.8 \pm 3.2$ & U-series & G4 & \multirow{4}{*}{$125-149$} \\
\hline LIMII7 & $105.1 \pm 4.2$ & U-series & G4 & \\
\hline Era-2 & $142 \pm 7$ & pIRIR & G4 & \\
\hline Era-0 & $131 \pm 6$ & pIRIR & G4 & \\
\hline Carrascos-3 & $191 \pm 17$ & pIRIR & G5 & \multirow{2}{*}{$145-208$} \\
\hline Era-1 & $152 \pm 7$ & $\begin{array}{l}\text { pIRIR } \\
\end{array}$ & G5 & \\
\hline
\end{tabular}

Table 3. Summary of new numerical ages in AMF and available ages from Ortuño et al. (2012). New datings in gray. Errors are given at the $1 \sigma$ confidence level. Legend: TL, thermoluminescence; pIRIR, elevated-temperature infared stimulated luminescence.

\subsubsection{Slip rate calculation}


The application of the Zechar and Frankel (2009) functions yields nine slip rates for the different strands of the Goñar-Lorca section of the AMF (Table 4) with mean values between 0.4 and $1.9 \mathrm{~mm} / \mathrm{yr}$. We first analyzed the lateral slip rates obtained for each fault strand separately. The first group of offsets (114-115) is entrenched in slope debris above the G2 alluvial fan (Fig. 3). Using the age of G2 alluvial fan as the maximum age for the channel, the slip rates obtained from offsets 114 and 115 differ slightly (0.8-1.7 to 1.5-2.4 mm/yr; Table 4). This difference might be explained because: a) the entrenchment of all channels did not occur synchronously; or/and b) the largest offset corresponds to a channel entrenched with an initial non tectonic deflection coincident with the fault (invalidating our assumption that considers as default no initial deflection). No counterscarp, morphological evidence or lithological change account for explanation "b” and, thus, “a” is considered as the most plausible one. The two slip rates intersect at 1.5-1.7 mm/yr, and, thus, we consider this range as the preferred value for this fault strand (Figure 3E and Table 3).

For the second group of offsets measured along the same fault strand (122-124, faultF2; Fig. 3), the calculated minimum lateral slip rates intersect at $0.7 \mathrm{~mm} / \mathrm{yr}$ (Table 4). Southwestwards, this fault strand splits in two (F2a and F2b). Along F2b we have identified an offset (136) with associated age information (this channel is entrenched in G5 alluvial fan deposits). The calculated minimum lateral slip rate is $0.3-0.6 \mathrm{~mm} / \mathrm{yr}$, smaller than the calculated slip rate for the fault-F2. Nevertheless, these results are consistent because the slip rate on F2 is split between F2a and F2b. Notice that the older age of the units (G3 to G5), the larger the calculated slip rate (Table 4). This reduction of the tectonic activity in the area from the middle Pleistocene and early Late Pleistocene has also been suggested by Silva et al. (1992) and Silva (1994). In the Huércal-Overa Basin, García-Meléndez (2000) and García-Meléndez et al. (2003) also detected this general decrease in the tectonic activity through the fact that Late Pleistocene and Holocene landforms are less affected by tectonic deformations.

The slip rate along one single strand should be approximately equal to the sum of rates along the different faults in which it splits, when no ductile deformation or distributed deformation is present. To verify this assertion at the AMF, we compared the 1.5-1.7 $\mathrm{mm} / \mathrm{yr}$ lateral minimum slip rate obtained from offsets 114 and 115 with the individual contribution of the sub-parallel strands of the horse tail termination. We summed the slip rates for the sub-parallel fault strands: 1) fault-F1 (129), 0.3-0.7 mm/yr; 2) fault-F2 
(122-124), $0.7 \mathrm{~mm} / \mathrm{yr}$; and 3) southernmost strand (125), 0.6-1.7 mm/yr (Fig. 4B and Table 4), and we obtained 1.6-3.1 mm/yr. The slip rates estimated are compatible, as they intersect with the values for offsets 114 and 115 in the interval 1.6-1.7 mm/yr for the last $200 \mathrm{ka}$. Therefore, we considered this value the minimum lateral slip rate for the Goñar-Lorca section of the AMF.

\begin{tabular}{|c|c|c|c|c|c|c|c|c|c|}
\hline \multicolumn{2}{|r|}{ Offset } & \multicolumn{2}{|c|}{ Age } & \multicolumn{5}{|c|}{ Slip rate } & Fault \\
\hline 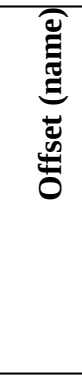 & 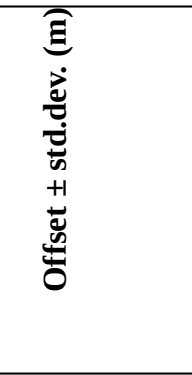 & 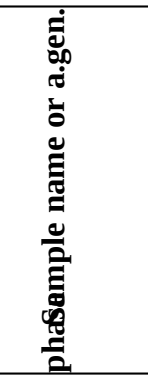 & 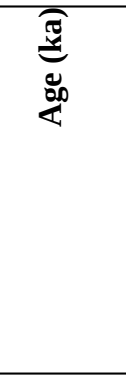 & 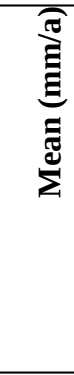 & 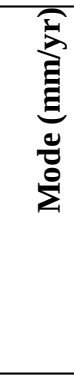 & 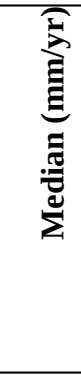 & 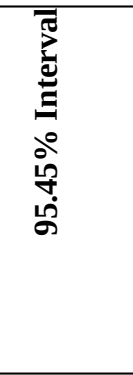 & 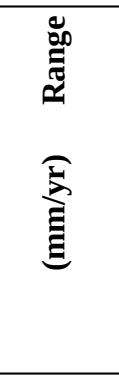 & \\
\hline 114 & $26.24 \pm 4.58$ & $\mathrm{G} 2$ & $23 \pm 2$ & 1.2 & 1.1 & 1.1 & $+0.5 /-0.4$ & $0.8-1.7$ & AMF \\
\hline 114 & $17.10 \pm 8.20$ & G2 & $23 \pm 2$ & 0.8 & 0.7 & 0.7 & $+0.8 /-0.7$ & $0.1-1.6$ & AMF \\
\hline 115 & $42.75 \pm 2.97$ & G2 & $23 \pm 2$ & 1.9 & 1.8 & 1.8 & $+0.5 /-0.4$ & $1.5-2.4$ & AMF \\
\hline 122 & $28.70 \pm 3.11$ & Carra-2-1 & $49 \pm 2$ & 0.6 & 0.6 & 0.6 & $+0.1 /-0.1$ & $0.5-0.7$ & F2 \\
\hline 123 & $\begin{array}{l}160.21 \pm 12.8 \\
0\end{array}$ & $\begin{array}{l}\text { Carrascos } \\
-3 \\
\end{array}$ & $191 \pm 17$ & 0.9 & 0.8 & 0.8 & $+0.2 /-0.2$ & $0.7-1.1$ & F2 \\
\hline 124 & $109.72 \pm 5.88$ & G4 & $125-149$ & 0.8 & 0.8 & 0.8 & $+0.2 /-0.1$ & $0.7-1.0$ & F2 \\
\hline 125 & $104.03 \pm 5.09$ & G3-G4 & $90-147$ & 0.9 & 0.8 & 0.9 & $+0.8 /-0.3$ & $0.6-1.7$ & South \\
\hline 129 & $38.24 \pm 6.65$ & G3-G4 & $90-147$ & 0.4 & 0.3 & 0.3 & $+0.3 /-0.1$ & $0.3-0.7$ & F1 \\
\hline 136 & $68.83 \pm 11.68$ & $\begin{array}{l}\text { Carrascos } \\
-3 \\
\end{array}$ & $191 \pm 17$ & 0.4 & 0.4 & 0.4 & $+0.2 /-0.1$ & $0.3-0.6$ & F2b \\
\hline
\end{tabular}

Table 4. Lateral slip rates resulting from the combination of morphotectonic analysis and numerical dating in Goñar-Lorca section of Alhama de Murcia fault. Channel 114 (see Fig. 4) was measured remotely and in the field: second row of results. The interpretation of each offset can be found in the supplementary material from S1-S8. Legend: a.gen., alluvial fan generation. The calculations were done applying Zechar and Frankel (2009) functions.

\subsection{Lorca-Totana section}

The Lorca-Totana fault section is $23 \mathrm{~km}$ long and has an orientation of N $060 \mathrm{E}$. In this section the fault splits into three major parallel strands (the NAMF, the SMAF and the fAMF; Fig. 2), and minor sub-parallel traces (Fig. 5). The NAMF and the f-AMF dip towards the NW, whereas the SMAF is sub-vertical in surface and the southeastern block is uplifted (Fig. 1C) as paleoseismic studies show (Martínez-Díaz et al., 2003; Masana et al., 2004; Ferrater et al., 2016). The most recent study in the El Saltador site 
(Ferrater et al., 2016) obtained a net slip rate of $0.9 \pm 0.1 \mathrm{~mm} / \mathrm{yr}$, and lateral and vertical slip rates of $0.9 \pm 0.1 \mathrm{~mm} / \mathrm{yr}$ and $0.1 \pm 0.0 \mathrm{~mm} / \mathrm{yr}$, respectively for the past $\sim 20 \mathrm{ka}$, using a buried paleochannel whose age is constrained between 15.2 ka (sample dated with Optically Stimulated Luminescence) and 22.1 ka (snail dated with radiocarbon technique). This net slip rate is 1.5 to 15 times higher than previous studies carried out in the same paleoseismological site (Martínez-Díaz et al., 2003; Masana et al., 2004). The main difference is the data in which the calculations are based. In the earlier cases, the slip rates were based on a vertical geomorphological slip and on the orientation of a slickenside, whereas the study of Ferrater et al. (2016) is based on a buried linear offset marker (a buried paleochannel exposed in the three-dimensional trenches), making the latter the most reliable and up to date slip rate.

The alluvial fan surfaces of this section show few preserved surface offset channels considered reliable markers (Fig. 2; Ferrater et al., 2015). Channel 055 (Fig. 2 and Fig. 4), affected by the SAMF fault activity (Fig. 2), is well preserved and may be considered a robust reconstructed offset due to the lack of headwaters of the southeastern wall (this has been evaluated with high subjective quality; Ferrater et al., 2015). We measured the offset of this channel remotely and in the field (Fig. 4). The two values are similar but the one calculated remotely has lower uncertainties (28.7 $\pm 2.7 \mathrm{~m}$ in front of $26.7 \pm 4.0 \mathrm{~m}$ from field measurements; Fig. 4).

This channel is affected by the fault strand that cuts the La Salud alluvial fan (SAMF; Fig. 2; the same strand where El Saltador paleoseismic site is) Dating results on the alluvial fan conducted by Canora et al. (2016) suggest that alluvial fan sedimentation was active at least until $28.2 \pm 2.0 \mathrm{ka}$ BP. Thus, the abandonment of the alluvial fan sedimentation and the entrenchment of channel 055 postdate $28.2 \mathrm{ka}$. As in the GoñarLorca section, the maximum age considered for the channel 055 is the age of the alluvial fan where it is entrenched. Considering the best constrained offset $(28.7 \pm 2.7$ $\mathrm{m})$ and its maximum age, we calculated a minimum lateral slip rate of $1.0 \pm 0.2 \mathrm{~mm} / \mathrm{yr}$ for the SAMF for the past $\sim 30 \mathrm{ka}$.

\section{Discussion}

5.1. Comparison between the values obtained here and the ones calculated in previous geomorphological analysis 
The offsets used here to calculate the slip rate of the AMF are comparable in size with those used by Martínez-Díaz et al. (2003) to calculate the slip rate at the Lorca-Totana section. On the contrary, these are smaller than those used by Martínez-Díaz (1998) and Ortuño et al. (2012) to estimate the slip rate of the Goñar-Lorca section. Therefore, in this last section, the results are less comparable as they may correspond to different time periods (assuming that more offset corresponds to a longer period of strain accumulation). Enhancement on the age constrains reinforces the certainty of the newly proposed slip rates.

The slip rates estimated for the southernmost termination of the Goñar-Lorca section (1.6-1.7 $\mathrm{mm} / \mathrm{yr}$ for the past $200 \mathrm{ka}$ ) are at the same magnitude order (but with no overlapping) to those calculated by Ortuño et al. (2012) that range between 0.95 and $1.37 \mathrm{~mm} / \mathrm{yr}$ for the past 125-1600 ka, even though the used control ages for the offset channels differ greatly. On the other hand, Martínez-Diaz (1998) provided a lower slip rate of $0.6 \mathrm{~mm} / \mathrm{yr}$ taking as a reference a channel being offset for more than $600 \mathrm{~m}$ and considering $1 \mathrm{Ma}$ as the maximum age of the drainage network. The comparison between all this values could eventually suggest an increase of the lateral slip rate of the AMF in the Goñar-Lorca section. However, the age of the offset channels used by Martínez-Díaz (1998) and Ortuño et al. (2012) to calculate the lateral slip rate is poorly constrained, evidencing that slip rate values are strongly dependent on the age uncertainties, and questioning the former suggestion.

In the Lorca-Totana section, although the surface offset measurement $(28.7 \pm 2.7 \mathrm{~m})$ is similar to the ones used by previous authors ( 26.7 m; Martínez-Díaz et al., 2003), the lateral slip rate obtained here is approximately five times larger than the one obtained by these authors. This is consequence of the improvement of the age control in this work, as Martínez-Díaz et al. (2003) assumed that the entrenchment of the channels occurred close to the middle-Upper Pleistocene boundary ( 130 ka).

\subsection{Comparison between the lateral slip rate obtained here and the one} obtained by trenching

The slip rates obtained in this study are based on morphotectonic evidences of slip. Recently, Ferrater et al. (2016) have updated the slip rates considering paleoseismic data. We compare here the two groups of values in order to infer the best methodology to be used in future studies. 
Comparing slip rates obtained with different methods is more reliable if the comparison is between two analyses carried out in the same site, i.e. the same alluvial fan. This is especially true when considering how much the surface slip observed after an earthquake varies along strike (e.g. Zielke et al., 2012). Here, we compare the offset of channelized unit D measured in the El Saltador alluvial fan (Ferrater et al., 2016), with the surface channel 055 measured in the La Salud alluvial fan. The comparison is reliable as: a) these two sites are just $1 \mathrm{~km}$ apart from each other (Figure 2), a distance we consider small to present large differences of slip, and b) the ages of these alluvial fans are similar being from the same depositional generation (Martínez-Díaz et al., 2003).

The channel in unit D at El Saltador is part of a buried channel sequence that infills a scar dug on top of the fan surface. This stratigraphic relation and the numerical ages suggest that the incision of unit D postdates the abandonment of the alluvial deposition on the fan surface which occurred between $\sim 15$ and 21 ka (Ferrater et al., 2016). The age of the channel on the La Salud alluvial fan surface is less constrained, being younger than the younger available age for the alluvial fan sequence dated by Canora et al. (2016) in $28.2 \mathrm{ka}$. The channel offsets in the El Saltador and in the La Salud alluvial fans are $16.3^{+2.7} /-0.3 \mathrm{~m}$ and $28.7 \pm 2.7 \mathrm{~m}$, respectively, being the surface channel offset obtained at La Salud larger than the offset of the paleochannel at El Saltador. This might seem surprising considering that the cumulative offset measured on the surface is normally expected to be equal or smaller than the offset of a buried paleochannel within the alluvial fan sequence. The reason is that older units have been affected by at least the same number of earthquakes of the channels in surface. The apparent inconsistence observed in the SAMF fault trace is due to the fact that the incision of the channel system of El Saltador alluvial fan occurred after the incision of the La Salud channel (055; Figure 2), the last one only constrained as a maximum age.

The stratigraphic and sedimentological analysis allowed us to compare the slip rates obtained using different methods: a) a $1.0 \pm 0.2 \mathrm{~mm} / \mathrm{yr}$ minimum lateral slip rate using the geomorphological analysis (past $\sim 30 \mathrm{ka}$ ), and b) a best estimate lateral slip rate of $0.9 \pm 0.1 \mathrm{~mm} / \mathrm{yr}$ obtained in the trenches (past $\sim 20 \mathrm{ka}$; Ferrater et al., 2016). The values intersect in the interval $0.8-1.0 \mathrm{~mm} / \mathrm{yr}$. For this reason, we considered this value to be the best constrained lateral slip rate of the SAMF of the Lorca-Totana section for the past $\sim 25$ ka. 
We encourage the combination of $3 \mathrm{D}$ trenching and surface analyses as they complement each other and may help to discard or strengthen the values obtained. However, we highlight the advantages and disadvantages of both techniques separately in Table 5. Paleoseismic trenching permits a precise analysis (small uncertainties, good correlation) but it is a time and money-consuming process. On the other hand, morphological analyses, as long as the channels are preserved in anthropogenically modified sites, are much faster to analyze and for this rapidity we recommend using them especially where the fault under analysis splits into more than one strand. The principal disadvantage of the morphological analysis is the high uncertainties related to the age constraints of the channel. While it is usually assumed that channels postdate the abandonment of the top surface fan sedimentation, some of them may have been intermittently active during the last alluvial events invalidating the dating assumptions. Moreover, the time lapse between the alluvial fan abandonment and the entrenchment of the channel is unknown. Dating the base of the channel infill, if available, could provide a minimum age and enhance the results. The main limiting factors common for both methodologies are: a) the availability of young material affected by the fault activity, and b) the suitability to date this material (reduced if the affected units are proximal facies of alluvial fans, which may not be suitable for radiocarbon dating due to its lack of organic matter).

\begin{tabular}{|c|c|c|}
\hline & Morphotectonic analyses & Paleoseismic trenches \\
\hline 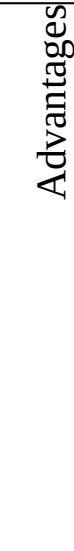 & $\begin{array}{l}\text { Suited where deformation affects several } \\
\text { sub-parallel fault strands } \\
\text { Fast and less expensive } \\
\text { Larger offsets can be measured }\end{array}$ & $\begin{array}{l}\text { Increased reliability in correlating offset } \\
\text { features (based on age, morphology and } \\
\text { facies) } \\
\text { Increased measurement precision, } \\
\text { smaller uncertainties } \\
\text { Increased accuracy in channel age } \\
\text { determination }\end{array}$ \\
\hline
\end{tabular}




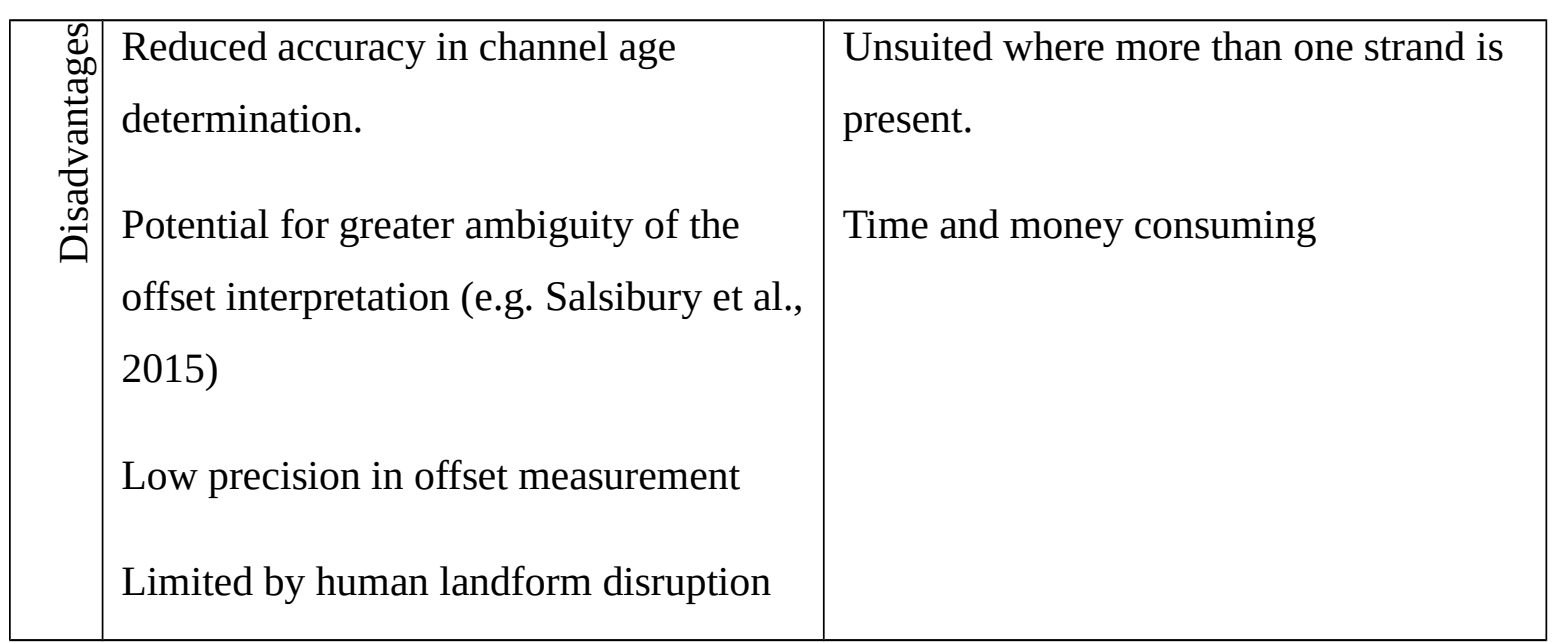

Table 5. Summary of the advantages and disadvantages of morphotectonic analyses and paleoseismic trenches in slip rate determination.

\subsection{Differences of slip rate along the AMF}

The lateral slip rates obtained for the two analyzed sections (1.6-1.7 mm/yr for the Goñar-Lorca section and 0.8-1.0 mm/yr for the SAMF for the Lorca-Totana section) are 1.5-15 times larger and have smaller associated uncertainties than the lateral and net slip rates calculated by previous authors (Martínez-Díaz et al., 2003; Masana et al., 2004; Ortuño et al., 2012). On the other hand, the slip rates obtained in this study support the geodetic interpretation of Echeverria et al. (2013) who suggest that most of their calculated horizontal deformation associated with the AMF and PF $(1.5 \pm 0.3$ $\mathrm{mm} / \mathrm{yr}$ ) may be absorbed by the AMF based on the seismicity distribution and evidence of Quaternary activity.

Ferrater et al. (2016) obtained a net slip rate for one of the three traces of the LorcaTotana fault section $(0.9 \pm 0.1 \mathrm{~mm} / \mathrm{yr})$ and our estimations for the lateral slip rate focus also in the same trace (SAMF; Fig. 5). Therefore, accounting for the unknown contribution of the NAMF and the f-AMF, the total net slip rate of the fault section is probably larger than this value. The shortening direction obtained by GNSS data analysis (Echeverria et al., 2013) is N 325 E. Therefore, according to the N 060 E strike of the overall Lorca-Totana section, the NAMF and the f-AMF could be absorbing a considerable amount of dip slip component. This is supported by: 1) the faceted spurs (Fig. 2), 2) the vertical relief associated to the NAMF and the f-AMF (Fig. 5), and 3) the dip-slip component of the Mw 5.2 Lorca earthquake (Fig. 1C) whose hypocenter was in the northern fault branch of the section and had a rupture directivity of $\sim \mathrm{N} 220^{\circ} \mathrm{E}$ 
(NAMF; López-Comino et al., 2012; Martínez-Díaz et al. 2012a). Although the geometry of this system in depth is not solved yet, according to these geomorphological observations and slip rate values, we suggest the slip partitioning between the strands of Lorca-Totana fault section; the SAMF may be absorbing most of the strike-slip deformation and a negligible dip-slip, whereas the other two fault strands would be accommodating most of the vertical component. Thus, the net slip rate of this section is expected to be larger than $0.9 \mathrm{~mm} / \mathrm{yr}$.

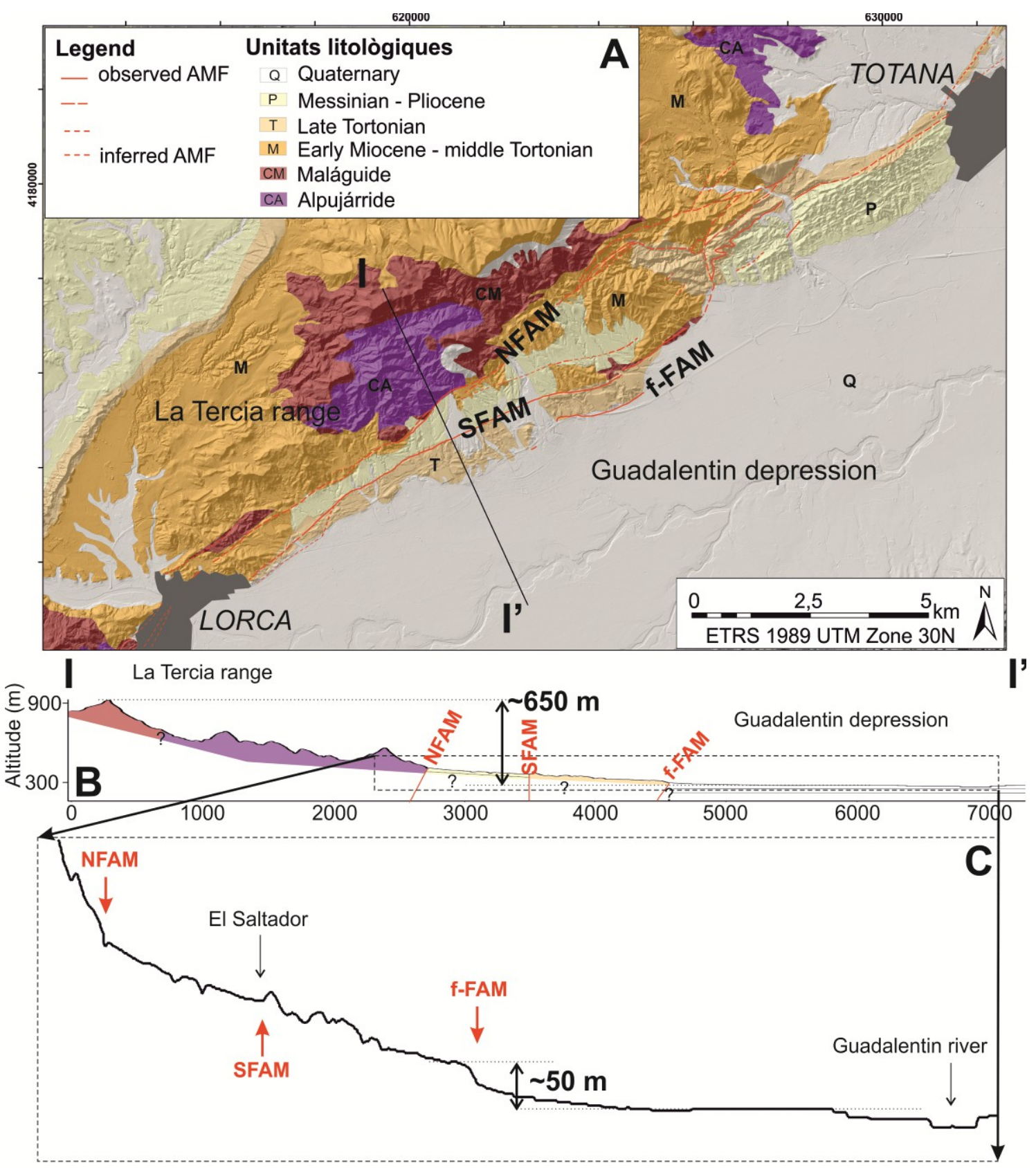

Figure 5. Vertical relief associated to fault strands NAMF and f-AMF of the LorcaTotana section. A) Geological map and situation of the geological profile (I-I'); B) 
geological profile I-I' perpendicular to the AMF strike where a vertical relief of $650 \mathrm{~m}$ between the Guadalentin depression and the upper part of the La Tercia range is estimated; C) topographic profile where a vertical relief associated with the f-AMF is measured.

All slip rate values estimated for the AMF suggest that the main lateral component of this fault is the lateral one. For example, In the Goñar-Lorca section, the summed vertical slip rates of all fault strands is 0.16-0.22 mm/yr since 47-63 ka (Ortuño et al., 2012), whereas we obtained a much larger value of lateral slip rate (1.6-1.7 mm/yr for the past $200 \mathrm{ka}$ ). However the ratio between the lateral and the vertical components of slip has to be taken with caution. Approximations on this ratio are done using data obtained by different methods which introduces uncertainty. For instance, MartínezDíaz et al. (2003) and Masana et al. (2004) estimated the vertical slip rate based on a topographical offset from which they suggested a lateral component based on the pitch of a slickenside; and Ortuño et al. (2012) calculated the vertical and the lateral slip rate by means of a paleoseismological study and a geomorphological analysis, respectively. On the other hand, the vertical component of the fault may have been underestimated by Ferrater et al. (2016). These authors used the same type of data to calculate the two components of slip, but they assumed that the offset of the buried channel occurred while it was not active otherwise the uplift of the southeastern wall during an earthquake would have triggered erosion of the channel in that wall, underestimating the vertical offset. As a result, their slip rate values constitute the maximum ratio between the lateral and the vertical component.

Even the slip rates of the two analyzed sections differ, additional data are required to confirm a clearly differentiated behavior between them, as: a) the offsets used to calculate the slip rate are not evenly distributed along the fault, b) the slip rates are incomplete for both sections (Goñar-Lorca section lacks information on the northern part, and no information is available for the northern (NAMF) and the frontal (f-AMF) fault strands of the Lorca-Totana section), and c) the results concern different periods of time. Moreover, more information is required to confirm the segmentation in terms of slip rate.

\subsection{Regional block motions}


Our results indicate much higher slip rates for the AMF than previous estimates, revealing it as one of the most active faults in the Eastern Betic Shear Zone (EBSZ), as we discuss in the following lines. The faults of this system have been the focus study of several authors aiming to obtain their seismic parameters (Fig. 6). In the Palomares fault (PF), Weijermars (1987) estimated a horizontal long-term slip rate of $2 \mathrm{~mm} / \mathrm{yr}$ for the past 7 Ma based on his estimation of the age of the basin and range structure (Fig. 6). On the other hand, GPS results in the AMF region suggest that the Alhama de Murcia and the Palomares faults together have $1.3 \pm 0.2 \mathrm{~mm} / \mathrm{yr}$ strike slip component (Echeverria et al., 2013). When this is compared with our estimation of the lateral slip rate, little deformation is left for the Palomares fault. Weijermars (1987) slip rate would match GPS and geological results only if a strong decrease in slip rate has taken place in time along the Palomares fault. In the SW segment of the Carrascoy fault (CF), MartínBanda et al. (2015) obtained a net slip rate of $0.37 \pm 0.08 \mathrm{~mm} / \mathrm{yr}$ through a paleoseismic analysis (since 210 ka; Fig. 6), with a prominent vertical component of slip. South of the CF, Insua-Arévalo et al. (2015) described Los Tollos fault (LTF) and estimated, by means of a paleoseismological approach, a net slip rate of 0.12-0.17 mm/yr (Fig. 6), considering most of it to be strike-slip. The obtained slip rates could confirm the deformation transference from the AMF to the Los Tollos and Carrascoy faults to the northeast (Fig. 6). The proposed vertical slip rate of Bajo Segura blind thrust fault (BSF) is 0.1-0.3 mm/yr for the Quaternary period (Alfaro et al., 2012). Finally, to the south, at the Carboneras fault, Moreno et al. (2015) obtained a minimum lateral slip rate of 1.31 $\mathrm{mm} / \mathrm{yr}$ for the last $113 \mathrm{ka}$, a value that is close to that of the GPS results (Echeverria et al., 2015) and that is also consistent with those at the AMF.

The compiled values suggest that long-term slip rates are apparently larger than the short-term slip rates for the faults in the EBSZ, and thus a decrease of the slip rates ocurred. The representability and validity of such a decrease in slip rate will benefit of additional data for different fault segments and the availability of data for a larger number of structures. Even if regarded with caution, we would like to highlight that one possible explanation of the apparent decrease in the short-term slip rate might be related with the fact that the faults are part of a diffuse plate boundary. Berryman et al. (2012) remarked that complex and low-slip rate deformation zones characterized by networked structures are characterized by aperiodic recurrence, contrasting with an opposite "end member” with periodic behavior represented by isolated structures located at plate 
boundaries. These authors analyze the earthquake chronology of faults within the Dead Sea transform fault zone as an example of scattered occurrence of earthquakes. Considering that the behavior of faults within the EBSZ might be close to the aperiodic behavior end-member, we propose to interpret that the lower short-term slip rates might be apparent and produced by the fact that the number of earthquake clusters might be smaller when analyzing shorter time periods than when integrating a longer earthquake history. However, a real decrease in the deforming rates cannot be excluded.

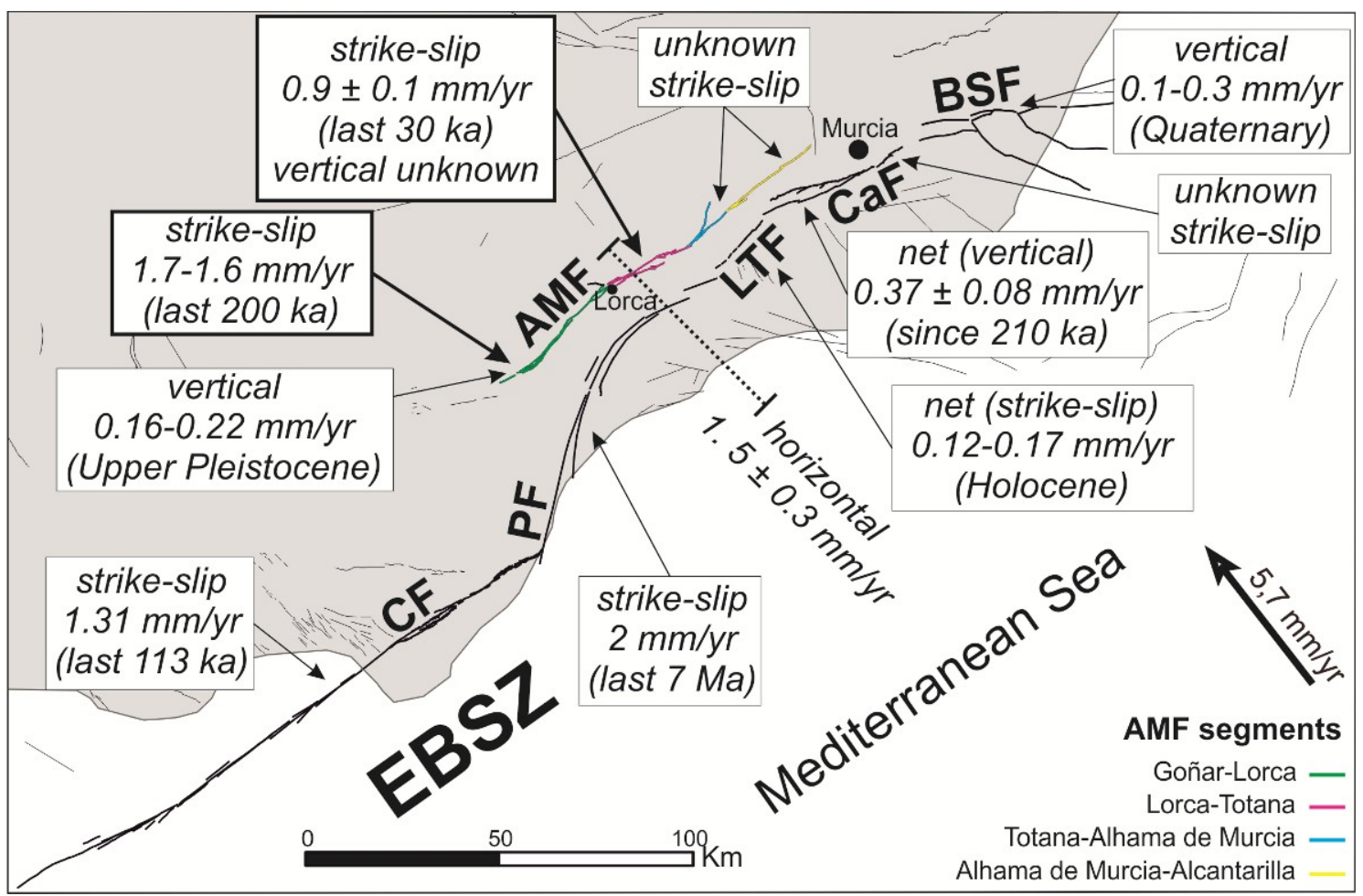

Figure 6. Summary of available slip rates for the Eastern Betics Shear Zone (EBSZ) faults (Weijermars, 1987; Alfaro et al., 2012; Ortuño et al., 2012; Echeverria et al., 2013; Moreno et al.,2015; Martín-Banda et al., 2015; this study). Legend: CF, Carboneras fault; PF, Palomares fault; LTF, Los Tollos fault; CAF, Carrascoy fault; BSF, Bajo Segura fault. Quaternary Active Faults Database of Iberia from IGME (2015). The dot line is the profile where Echeverria et al. (2013) projected the geodetic velocities. The arrow indicates the convergence direction between the Eurasian and African plates according to NNR-MORVEL56 model (Argus et al., 2011).

According to these values, the Alhama de Murcia and the Carboneras faults are the faults with the greatest strike slip component of the Eastern Betics Shear Zone for the last $~ 100$ ka. This deduction does not take into account the undetermined: 1) strike slip 
component along the NE segment of the Carrascoy fault, and b) the strike slip value of the recent period of time of the Palomares fault. Future studies concerning slip rates within the EBSZ should focus on the sections of the AMF compressed between Totana and Alcantarilla, and the short term slip rate of the Palomares fault based on geological data.

\section{Conclusions}

We obtained the lateral slip rate of the strike-slip Alhama de Murcia fault applying a morphotectonic analysis, getting minimum lateral slip rates of 1.6-1.7 mm/yr (for the past $\sim 200 \mathrm{ka}$ ) and $1.0 \pm 0.2 \mathrm{~mm} / \mathrm{yr}$ (for the last $30 \mathrm{ka}$ ) for the Goñar-Lorca and LorcaTotana sections, respectively. These values agree with recent geodetic estimations of 1.5 $\pm 0.3 \mathrm{~mm} / \mathrm{yr}$ of horizontal slip accommodated by the AMF and the Palomares fault and, in consequence, indicate a much lower slip rate along the latter. Moreover, the lateral slip rate calculated for the SAMF fault strand in the Lorca-Totana section $(1.0 \pm 0.2$ $\mathrm{mm} / \mathrm{yr}$ ) agrees with those calculated for the same fault strand by a previous paleoseismic study $(0.9 \pm 0.1 \mathrm{~mm} / \mathrm{yr})$. The slip rates obtained for the SAMF of the Lorca-Totana section combined with geomorphologic observations (vertical uplift) controlled probably by the two other subparallel faults of the section (NAMF and fAMF) suggest partitioning, being the lateral slip absorbed by the SAMF and the dip slip by the NAMF and the f-AMF. Our results are in agreement with previous studies in the Eastern Betics Shear Zone, which point out that the Alhama de Murcia and the Carboneras faults are the most known active strike-slip faults with a reverse component of the system, as Bajo Segura and Carrascoy fault have a larger dip slip component and the short-term slip rate of the Palomares fault is unknown.

Morphotectonic analyses and 3D paleoseismic trenching are complementary having each methodology advantages and disadvantages. For instance, trenching provides the most precise measurement of slip rate, whereas morphotectonic analysis can be used to evaluate slip rates at more sites and at a lower cost. In faults with scarce evidences of acivity, the use of the two techniques is desirable, since measurable offsets may be rare, but a deep discussion is needed when measuring channel offsets both buried and in surface in the same site.

\section{Acknowledgements}


This research was funded by SHAKE CGL2011-30005-C02-02, RISKNAT2014SGR/1243 and PREVENT (CGL2015-66263-R). H. Perea was a fellow researcher under the "Juan de la Cierva” program. The Ministerio de Educación, Cultura y Deporte

from Spain provided funding for the predoctoral FPU fellowship of M. Ferrater.

\section{REFERENCES:}

Alfaro,P., Bartolomé, R., Borque, M.J., Estévez, A., García-Mayordomo, J., García-Tortosa, F.J., Gil, A.J., Gràcia, E., Lo Iacono, C., Perea, H., 2012. The Bajo Segura Fault Zone: Active blind thrusting in the Eastern Betic Cordillera (SE Spain). Journal of Iberian Geology 38, 271-284.

Amundson, R., Wang, Y.R., Chadwick, O.A., Trumbore, S.E., McFadden, L., McDonald, E., Wells, S., and DeNiro, M., 1994. Factors and processes governing the ${ }^{14} \mathrm{C}$ content of carbonate in desert soil. Earth and Planetary Science Letters 125, 385-405.

Argus, D.F., Gordon, R.G., Demets, C., 2011. Geologically currentmotion of 56 plates rela- tive to the nonet-rotation reference frame. Geochemistry, Geophysics, Geosystems 12 (11), doi.org/10.1029/2011GC003751.

Arkley, R.J., 1963. Calculation of carbonate and water movement in soil from climatic data. Soil Science 96, 239-248.

Berryman, K.R., Cochran, U.A., Clark, K.J., Biasi, G.P., Langridge,R. M., Villamor, P., 2012. Major Earthquakes Occur Regularly on an Isolated Plate Boundary Fault. Science 336, 1690-1693.

Birkland, P. W. (1999), Soils and Geomorphology, 3rd ed., Oxford University Press, New York.

Blisniuk, K., Oskin, M., Fletcher, K., Rockwell, T., Sharp, W., 2012. Assessing the reliability of U-series and 10Be dating techniques on alluvial fans in the Anza Borrego Desert, California. Quaternary Geochronology 13, 26-41, doi: 10.1016/j.quageo.2012.08.004.

Bousquet, J., 1979. Quaternary strike-slip faults in south-eastern Spain. Tectonophysics 52, 277-286.

Campbell, G.E., Walker, R.T., Abdrakhmatov, K., Schwenninger, J., Jackson, J., Elliott, J.R., Copley, A., 2013. The Dzhungarian fault: Late Quaternary tectonics and slip rate of a major right-lateral strike-slip fault in the northern Tien Shan region. Journal of Geophysical Research: Solid Earth 118 (10), 5681-5698, doi: 10.1002/jgrb.50367.

Canora, C., Roca, C., Martínez-Díaz, J., Insua-Arévalo, J. M., Martín-González, F., Gómez-Ortiz, D., Martínez-Pagan, P., Masana, E., Ortuño, M., Ferrater, M., Medialdea, A. (accepted). Nuevos datos de actividad paleosísmica de la falla de Alhama de Murcia en el abanico de La salud (segmento Lorca-Totana de la Falla de Alhama de Murcia), Béticas orientales. IX Congreso Geológico de España

Capo, R.C. and Chadwick, O.A., 1999. Sources of strontium and calcium in desert soils and calcrete. Earth and Planetary Science Letters 170, 61-72.

Cerling, T.E., 1999. Stable carbon isotopes in paleosol carbonates. Special Publication of the International Association of Sedimentologists 27, 43-60.

Chevalier, M.L., Tapponnier, P., Van der Woerd, J., Ryerson, F.J., Finkel, R.C., Li, H., 2012. Spatially constant slip rate along the southern segment of the Karakorum fault since 200ka. Tectonophysics 530-531, 152-179, doi: 10.1016/j.tecto.2011.12.014.

Echeverria, A., Khazaradze, G., Asensio, E., Gárate, J., Martín Dávila, J., Suriñach, E., 2013. Crustal deformation in eastern Betics from CuaTeNeo GPS network. Tectonophysics 608, 600-612.

Echeverria, A., Khazaradze, G., Asensio, E., Masana, E., 2015. Geodetic evidence for continuing tectonic activity of the Carboneras fault (SE Spain). Tectonophysics 663, 302-309, doi: 10.1016/j.tecto.2015.08.009.

Ferrater, M., Arrowsmith, R., Masana, E., 2015. Lateral offset quality rating along low slip rate faults: application to the Alhama de Murcia fault (SE Iberian Peninsula). Remote sensing 7, 1482714852.

Ferrater, M., Ortuño M., Masana, E., Pallàs, R., Perea, H., Baize, S., García-Meléndez, E., Martínez-Díaz, J.J., Echeverría, A., Rockwell, T., Sharp, W.D., Medialdea, A., Rhodes, E., 2016. Refining seismic parameters in lowseismicity areas by 3D trenching: The Alhama de Murcia fault, SE Iberia. Tectonophysics 680, 122-128. Doi: 10.1016/j.tecto.2016.05.020

Ferry, M., Meghraoui, M., Karaki, N.A., Al-Taj, M., Amoush, H., Al-Dhaisat, S., Barjous, M., 2007. A 48-kyr-long slip rate history for the Jordan Valley segment of the Dead Sea Fault. Earth and Planetary Science Letters 260, 394-406, doi: 10.1016/j.epsl.2007.05.049. 
Fletcher, K. E. K., Rockwell, T. K., Sharp, W. D., 2011. Late Quaternary slip rate of the southern Elsinore fault, Southern California: Dating offset alluvial fans via $230 \mathrm{Th} / \mathrm{U}$ on pedogenic carbonate. Journal of Geophysical Research 116, 1-11. doi: 10.1029/2010JF001701

Frankel, K.L., Dolan, J.F., Finkel, R.C., Owen, L. A., Hoeft, J.S., 2007. Spatial variations in slip rate along the Death Valley-Fish Lake Valley fault system determined from LiDAR topographic data and cosmogenic 10 Be geochronology. Geophysical Research Letters 34 (18), L18303, doi: 10.1029/2007GL030549.

Fu, B., Awata, Y., Du, J., He, W., 2005. Late Quaternary systematic stream offsets caused by repeated large seismic events along the Kunlun fault, northern Tibet. Geomorphology 71, 278-292, doi: 10.1016/j.geomorph.2005.03.001.

García-Meléndez, E., 2000. Geomorfología y Neotectónica del Cuaternario de la Cuenca de HuércalOvera y Corredor del Almanzora. Análisis y Cartografía mediante Teledetección y SIG. Ph.D. thesis, Salamanca, Spain, Universidad de Salamanca, 528 p.

García-Meléndez, E., Goy, J.L., Zazo, C., 2003. Neotectonica and Plio-Quaternary landscape development within the eastern Huércal-Overa Basin (Betic Cordilleras, southeastern Spain). Geomorphology 50, 111-133, doi:10.1016/S0169-555X(02)00210-6.

Gile, L.H., Peterson, F.F., Grossman, R.B., 1966. Soil science 101, 347-360.

Gold, R.D., Cowgill, E., Arrowsmith, J.R., Chen, X., Sharp, W.D., Cooper, K.M., Wang, X.-F., 2011. Faulted terrace risers place new constraints on the late Quaternary slip rate for the central Altyn Tagh fault, northwest Tibet. Geological Society of America Bulletin 123 (5-6), 958-978, doi: 10.1130/B30207.1.

Gold, P.O., Behr, W.M., Rood, D., Sharp, W.D., Rockwell, T.K., Kendrick, K., Salin, A., 2015. Holocene geologic slip rate for the Banning strand of the southern San Andreas Fault, southern California. Journal of Geophysical Research-Solid Earth 120, doi:10.1002/2015JB012004.

Hall, N.T., Wright, H., Clahan, K.B., 1999. Paleoseismic studies of the San Francisco Peninsula segment of the San Andreas Fault zone near Woodside, California. Journal of Geophysical Research 104, 23215-23236.

IGME, 2015. QAFI v.3: Quaternary Active Faults Database of Iberia. Accessed on 15th of February 2016, http://info.igme.es/QAFI

IGN (Instituto Geográ fico Nacional), 2016. Catálogo de terremotos. Accessed on March 2016. http://www.ign.es/ign/layoutIn/sismoFormularioCatalogo.do.

Insua-Arévalo, J. M., García-Mayordomo, J., Salazar, A., Rodríguez-Escudero, E., Martín-Banda, R., Álvarez-Gómez, J. A., Canora, C., Martínez-Díaz, J. J., 2015. Paleoseismological evidence of holocene activity of the Los Tollos fault (Murcia, se Spain): A lately formed quaternary tectonic feature of the eastern betic shear zone. Journal of Iberian Geology 41(3), 333-350. doi: 10.5209/rev_JIGE.2015.v41.n3.49948

Ku, T. L., Bull, W. B., Freeman, S. T., Knauss, K. G., 1979. Th 230 -U 234 dating of pedogenic carbonates in gravelly desert soils of Vidal Valley, southeastern California. Geological Society of America 90, 1063-1073.

De Larouziére, F.D., Bolze, J., Bordet, P., Hernández, J., Montenat, C., Ott d’Estevou, P., 1988. The Betic segment of the lithospheric Trans-Alboran shear zone during the Late Miocene. Tectonophysics 152, 41-52.

Libby, W.F., 1955. Radiocarbon dating. Segond edition, University of Chicago Press, Chicago.

Lindvall, S.C., and Rockwell, T.K., 1995. Holocene activity of the Rose Canyon fault zone in San Diego, California. Journal of Geophysical Research 100, 24121-24132.

Liu-Zeng, J., Klinger, Y., Sieh, K., Rubin, C., Seitz, G., 2006. Serial ruptures of the San Andreas fault, Carrizo Plain, California, revealed by three-dimensional excavations. Journal of Geophysical Research 111, p. B02306, doi: 10.1029/2004JB003601.

López-Comino, J.Á., Mancilla, F.D.L., Morales, J., Stich, D., 2012. Rupture directivity of the 2011, Mw 5.2 Lorca earthquake (Spain). Geophysical Research Letters 39, 1-5, doi: 10.1029/2011GL050498.

Ludwig, K.R., and Paces, J.B., 2002. Uranium-series dating of pedogenic silica and carbonate, Crater Flat, Nevada. Geochimica et Cosmochimica Acta 66 (3), 487-506.

Machette, M.N., 1985. Calcic soils of the southwestern United States. Geological Society of America 203, 1-21.

Marco, S., Rockwell, T.K., Heimann, A., Frieslander, U., Agnon, A., 2005. Late Holocene activity of the Dead Sea Transform revealed in 3D palaeoseismic trenches on the Jordan Gorge segment. Earth and Planetary Science Letters 234, 189-205, doi: 10.1016/j.epsl.2005.01.017. 
Martín, R., Stich, D., Morales, J., Mancilla, F. (2015). Moment tensor solutions for the Iberian-Maghreb region during the IberArray deployment (2009-2013). Tectonophysics 663, 261-274. doi: 10.1016/j.tecto.2015.08.012

Martín-Banda, R., García-Mayordomo, J., Insua-Arévalo, J.M., Salazar, Á.E., Rodríguez-Escudero, E., Álvarez-Gómez, J.A., Medialdea, A., Herrero M.J., 2015. New insights on the seismogenic potential of the Eastern Betic Shear Zone (SE Iberia): Quaternary activity and paleoseismicity of the SW segment of the Carrascoy Fault Zone. Tectonics 34, doi:10.1002/2015TC003997.

Martínez-Díaz, J.J., 1998. Neotectónica y Tectónica Activa del Sector Centro-Occidental de la Región de Murcia y Sur de Almería (Cordillera Bética - España). Ph.D. thesis, Madrid, Spain, Universidad Complutense de Madrid.

Martínez-Díaz, J.J., and Hernández-Enrile, J.L., 2001. Using travertine deformations to characterize paleoseismic activity along an active oblique-slip fault: the Alhama de Murcia fault (Betic Cordillera , Spain ). Acta Geologica Hispanica 36, 297-313.

Martínez-Díaz, J.J., Masana, E., Hernández-Enrile, J.L., Santanach, P., 2003. Effects of repeated paleoearthquakes on the Alhama de Murcia Fault ( Betic Cordillera , Spain ) on the Quaternary evolution of an alluvial fan System. Annals of geophysics 46, 775-791.

Martínez-Díaz, J. J., Bejar-Pizarro, M., Álvarez-Gómez, J. A., Mancilla, F. D. L., Stich, D., Herrera, G. Morales, J. (2012a). Tectonic and seismic implications of an intersegment rupture The damaging May 11th 2011 Mw 5.2 Lorca, Spain, earthquake. Tectonophysics 546-547, 28-37. doi: 10.1016/j.tecto.2012.04.010

Martínez-Díaz, J.J., Masana, E., and Ortuño, M., 2012b. Active tectonics of the Alhama de Murcia fault, Betic Cordillera, Spain. Journal of Iberian Geology 38, 253-270.

Martínez-Martínez, J.M., and Azañón, J.M., 1997. Mode of extensional tectonics in the southeastern Betics (SE Spain): Implications for the tectonic evolution of the peri-Alborán orogenic system. Tectonics 16, 205-225

Masana, E., Martínez-Díaz, J.J., Hernández-Enrile, J.L., Santanach, P., 2004. The Alhama de Murcia fault (SE Spain), a seismogenic fault in a diffuse plate boundary: Seismotectonic implications for the Ibero-Magrebian region. Journal of Geophysical Research 109, 1-17, doi: 10.1029/2002JB002359.

Meijninger, B.M.L., and Vissers, R.L.M., 2006. Miocene extensional basin development in the Betic Cordillera, SE Spain revealed through analysis of the Alhama de Murcia and Crevillente Faults. Basin Research 18, 547-571, doi: 10.1111/j.1365-2117.2006.00308.x.

Montenat, C., Ott d’Estevou, P., Delort, T., 1990. Le Basin de Lorca. In: Montenat, C. (Ed.), Les bassins Neogenes du Domaine Betique Oriental (Espagne), Documents et Travaux, 261-280.

Moreno, X., 2011. Neotectonic and Paleoseismic Onshore-Offshore Integrated Study of the Carboneras Fault (Eastern Betics, SE Iberia). Ph.D. thesis, Barcelona, Spain, Universitat de Barcelona

Moreno, X., Masana, E., Pallàs, R., Gràcia, E., Rodés, Á., Bordonau, J., 2015. Quaternary tectonic activity of the Carboneras Fault in the La Serrata range (SE Iberia): Geomorphological and chronological constraints. Tectonophysics 663, 78-94, doi: 10.1016/j.tecto.2015.08.016.

Nocquet, J.M., 2012. Present-day kinematics of the Mediterranean: A comprehensive overview of GPS results. Tectonophysics 579, 220-242, doi: 10.1016/j.tecto.2012.03.037.

Ortuno, M., Masana, E., Garcia-Melendez, E., Martinez-Diaz, J., Stepancikova, P., Cunha, P.P., Sohbati, R., Canora, C., Buylaert, J.P., Murray, A.S., 2012. An exceptionally long paleoseismic record of a slow-moving fault: The Alhama de Murcia fault (Eastern Betic shear zone, Spain). Geological Society of America Bulletin 124, 1474-1494, doi: 10.1130/B30558.1.

Rittase, W.M., Kirby, E., McDonald, E., Walker, J.D., Gosse, J., Spencer, J.Q.G., Herrs, A.J., 2014. Temporal variations in Holocene slip rate along the central Garlock fault, Pilot Knob Valley, California. Lithosphere 6, 48-58, doi: 10.1130/L286.1.

Rodés, Á., Pallàs, R., Braucher, R., Moreno, X., Masana, E., Bourlés, D.L., 2011. Effect of density uncertainties in cosmogenic 10Be depth-profiles: dating a cemented Pleistocene alluvial fan (Carboneras Fault, SE Iberia). Quaternary Geochronology 6, 186-194. doi:10.1016/j.quageo.2010.10.004

Rockwell, T., Loughman, C., Merifield, P., 1990. Late Qua- ternary rate of slip along the San Jacinto fault zone near Anza, Southern California. Journal of Geophysical Research 95, 8593-8605.

Rodríguez-Fernández, J., Azor, A., Azañón, J.M., 2012. The Betic intramontane basins (SE spain): stratigraphy, subsidence, and tectonic history. In: Busby, C., Azor, A. (Eds.), Tectonics of Sedimentary Basins: Recent Advances, Blackwell Publishing Ltd, 23, 461-479

Salisbury, J.B., Rockwell, T.K., Middleton, T.J., Hudnut, K.W., 2012. LiDAR and Field Observations of Slip Distribution for the Most Recent Surface Ruptures along the Central San Jacinto Fault. Bulletin of the Seismological Society of America 102, 598-619, doi: 10.1785/0120110068. 
Schaetzl, R.J. and Anderson, S., 2005. Soil Genesis and geomorphology. Cambridge University Press, Cambridge. $817 \mathrm{p}$

Serpelloni, E., Vannucci, G., Pondrelli, S., Argnani, A., Casula, G., Anzidei, M., Baldi, P., Gasperini, P., 2007. Kinematics of the western Africa-Eurasia plate boundary from focal mechanisms and GPS data. Geophysical Journal International 169 (3), 1180-1200. http://dx.doi. org/10.1111/j.1365246X.2007.03367.x.

Sharp, W.D., Ludwig, K.R., Chadwick, O.A., Amundson, R., Glaser, L.L., 2003. Dating fluvial terraces by $230 \mathrm{Th} / \mathrm{U}$ on pedogenic carbonate, Wind River Basin , Wyoming. Quaternary Research 59, 139-150, doi: 10.1016/S0033-5894(03)00003-6.

Silva, P.G., 1994. Evolución Geodinámica de la Depresión del Guadalentín desde el Mioceno superior hasta la Actualidad: Neotectónica y Geomorfología. Ph.D. thesis, Madrid, Spain, Universidad Complutense de Madrid, 642 p.

Silva, P., Goy, J.L., Zazo, C., 1992. Discordancias progresivas y expresión geomorfológica de los abanicos aluviales cuaternarios de la depresión tectónica del Guadalentín. Geogaceta 11, 67-70.

Silva, P.G., Bardají, T., Calmel-Avila, M., Goy, J.L., Zazo, C., 2008. Transition from alluvial to fluvial systems in the Guadalentín Depression (SE Spain) during the Holocene: Lorca Fan versus Guadalentín River. Geomorphology 100, 140-153, doi: 10.1016/j.geomorph.2007.10.023.

Soler, R., Masana, E., Santanach, P., 2003. Evidencias Geomorfológicas y estructurales del levantamiento tectónico reciente debido al movimiento inverso de la terminación sudoccidental de la Falla Alhama de Murcia (Cordillera Bética Oriental). Revista Sociedad Geológica España 16, 123134.

Van der Woerd, J., Tapponnier, P., Ryerson, F.J., Meriaux, A., Meyer, B., Gaudemer, Y., Finkel, R.C., Caffee, M.W., Guoguang, Z., Zhiqin, X., 2002. Uniform postglacial slip-rate along the central $600 \mathrm{~km}$ of the Kunlun Fault (Tibet), from 26Al, 10Be, and 14C dating of riser offsets, and climatic origin of the regional morphology. Geophysical Journal International 148, 356-388.

Vanneste, K., Radulov, A., De Martini, P., Nikolov, G., Petermans, T., Verbeeck, K., Camelbeeck, T., Pantosti, D., Dimitrov, D., Shanov, S., 2006. Paleoseismologic investigation of the fault rupture of the 14 April 1928Chirpan earthquake (M 6.8), southern Bulgaria. Journal of Geophysical Research 111, B01303, doi:10.1029/2005JB003814

Weijermars, R., 1987. The Palomares brittle-ductile Shear Zone of southern Spain. Journal of Structural Geology 9, 139-157.

Wesnousky, S.G., Prentice, C.S., Sieh, K.E., 1991. An offset Holocene stream channel and the slip rate along the northern reach of the San Jacinto fault zone, San Bernardino Valley, California. Geological Society of America Bulletin 103, 700-709.

Zechar, J.D., and Frankel, K.L., 2009. Incorporating and reporting uncertainties in fault slip rates. Journal of Geophysical Research 114, B12407, doi: 10.1029/2009JB006325.

Zielke, O., Arrowsmith, J.R., Grant Ludwig, L., Akciz, S.O., 2012. High-Resolution Topography-Derived Offsets along the 1857 Fort Tejon Earthquake Rupture Trace, San Andreas Fault. Bulletin of the Seismological Society of America 102, 1135-1154, doi: 10.1785/0120110230. 


\begin{tabular}{|c|c|c|c|c|c|c|c|}
\hline $\begin{array}{l}\text { Study } \\
\text { reference }\end{array}$ & $\begin{array}{l}\text { Martínez-Díaz et } \\
\text { al., 2001; Masana } \\
\text { et al., 2004 }\end{array}$ & \multicolumn{2}{|c|}{$\begin{array}{l}\text { Martínez-Díaz et al., } \\
2003\end{array}$} & \multicolumn{2}{|c|}{ Ortuño et al., 2012} & $\begin{array}{l}\text { Silva et al., } \\
1992\end{array}$ & $\begin{array}{l}\text { Soler } \\
\text { et al., } \\
2003\end{array}$ \\
\hline Study area & Lorca-Totana & \multicolumn{2}{|c|}{ Lorca-Totana } & \multicolumn{2}{|l|}{ Goñar } & AMF & AMF \\
\hline \multirow{4}{*}{ 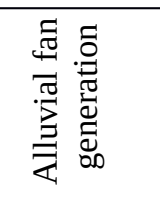 } & & $\mathrm{F}$ & Hol.-L. Pleist & G0 & Hol & 3r phase & G7 \\
\hline & Young & $E$ & Hol.-L. Pleist & G1-G2 & Hol.-L. Pleist & 2nd phase & G6 \\
\hline & Intermediate & D-C & L.-M. Pleist & G3-G4 & L.-M. Pleist & 1st phase & G4 \\
\hline & Old & C-B & M. Pleist-Plio & G5, G6 & M. Pleist & 1st phase & G3 \\
\hline
\end{tabular}

Table 1. Correspondence between alluvial fan generations described by previous stydies based on relative criteria, such as spatial relationships and entrenchment (Silva et al., 1992; Martínez-Díaz et al., 2001; Martínez-Díaz et al., 2003; Soler et al., 2003; Masana et al., 2004; Ortuño et al., 2012). Second row refers to the study area. Hol., Holocene; L., Late; M., Middle; Pleist., Pleistocene; Plio., Pliocene.

\begin{tabular}{|c|c|c|c|}
\hline Sample Name & Fault section & Preferred U-Th Age (ka, \pm ka) & Probability \\
\hline SALT13A16 & \multirow{3}{*}{ Lorca-Totana } & $12.39 \pm 0.42$ & 0.88 \\
\hline SALT13B19 & & $20.9 \pm 2.5$ & 0.62 \\
\hline SALT5CAN & & $11.0 \pm 1.7$ & 0.97 \\
\hline CARR4 & \multirow{5}{*}{ Goñar-Lorca } & $23.2 \pm 4.2$ & 0.95 \\
\hline LiM4 & & $11.7 \pm 2.6$ & 0.84 \\
\hline LIMII5 & & $46.6 \pm 5.7$ & 0.75 \\
\hline $\begin{array}{l}\text { PERA } \\
\end{array}$ & & $23.8 \pm 3.2$ & 0.76 \\
\hline LIM II7 & & $105.1 \pm 4.2$ & 0.12 \\
\hline
\end{tabular}

Table 2. Weighted mean ages for pedogenic carbonate samples. The mean is calculated using the three oldest samples of Table S1 (Supplementary material). Probability indicates the probability that the observed scatter is due to analytical errors.

\begin{tabular}{|c|c|c|c|c|}
\hline Sample & Age (ka) & Method & $\begin{array}{l}\text { Depositional phase } \\
\text { (Ortuño et al., 2012) }\end{array}$ & $\begin{array}{l}\text { Preferred age for the } \\
\text { alluvial fan generation }(\mathrm{ka})\end{array}$ \\
\hline Gaba-3 & $23 \pm 2$ & pIRIR & $\mathrm{G} 2$ & \multirow[t]{3}{*}{ 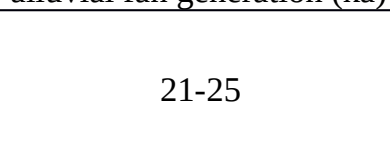 } \\
\hline CARR4 & $23.2 \pm 4.2$ & U-series & G2 & \\
\hline LIM4 & $11.7 \pm 2.6$ & U-series & G2 & \\
\hline Carr-1-2 & $52.4+7.9 /-6.4$ & TL & G3 & \multirow{7}{*}{$41-61$} \\
\hline Carra-2-1 & $49 \pm 2$ & pIRIR & G3 & \\
\hline Berm-1 & $46.3+6.1 /-5.1$ & TL & G3 & \\
\hline LIMII5 & $46.6 \pm 5.7$ & U-series & G3 & \\
\hline Era-4 & $58 \pm 3$ & pIRIR & G3 & \\
\hline Sard-2 & $61.9+15 /-11.2$ & TL & G3 & \\
\hline Sard-4 & $61 \pm 2$ & $\begin{array}{l}\text { pIRIR } \\
\end{array}$ & G3 & \\
\hline Carr-1 & $126+0 /-23$ & TL & G3-G4 & \multirow[t]{5}{*}{$90-147$} \\
\hline Gaba-2 & $108 \pm 8$ & pIRIR & G3-G4 & \\
\hline Gaba-1 & $111+36 /-21$ & TL & G3-G4 & \\
\hline Era-3 & $107 \pm 5$ & pIRIR & G3-G4 & \\
\hline Sard-1 & $120+39 /-21$ & TL & G3-G4 & \\
\hline
\end{tabular}




\begin{tabular}{|l|l|l|l|l|}
\hline Era- & $110+33 /-19$ & TL & G3-G4 & \\
\hline \multicolumn{5}{|l|}{} \\
\hline PERA & $23.8 \pm 3.2$ & U-series & G4 & \multirow{2}{*}{$125-149$} \\
\hline LIMII7 & $105.1 \pm 4.2$ & U-series & G4 & \\
\hline Era-2 & $142 \pm 7$ & pIRIR & G4 & \\
\hline Era-0 & $131 \pm 6$ & pIRIR & G4 & \multirow{2}{*}{$145-208$} \\
\hline \multicolumn{7}{|l|}{} & pIRIR & G5 & \\
\hline Carrascos-3 & $191 \pm 17$ & pIRIR & G5 & \\
\hline Era-1 & $152 \pm 7$ &
\end{tabular}

Table 3. Summary of new numerical ages in AMF and available ages from Ortuño et al. (2012). New datings in gray. Errors for radiocarbon dates are given at the $2 \sigma$ confidence level, whereas U-series, TL and OSL samples have $1 \sigma$ errors. Legend: pIRIR, post-IR IRSL. New ages in grey.

\begin{tabular}{|c|c|c|c|c|c|c|c|c|c|}
\hline \multicolumn{2}{|r|}{ Offset } & \multicolumn{2}{|c|}{ Age } & \multicolumn{5}{|c|}{ Slip rate } & Fault \\
\hline 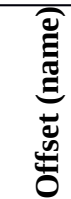 & 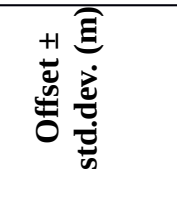 & 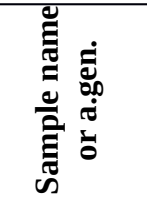 & 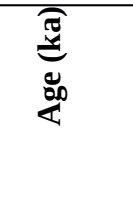 & 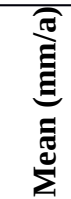 & 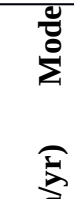 & 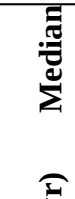 & 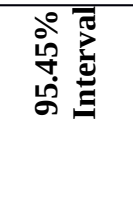 & 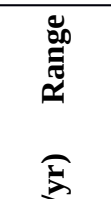 & \\
\hline 114 & $26.24 \pm 4.58$ & G2 & $23 \pm 2$ & 1.2 & 1.1 & 1.1 & $+0.5 /-0.4$ & $0.8-1.7$ & AMF \\
\hline 114 & $17.10 \pm 8.20$ & G2 & $23 \pm 2$ & 0.8 & 0.7 & 0.7 & $+0.8 /-0.7$ & $0.1-1.6$ & AMF \\
\hline 115 & $42.75 \pm 2.97$ & G2 & $23 \pm 2$ & 1.9 & 1.8 & 1.8 & $+0.5 /-0.4$ & $1.5-2.4$ & AMF \\
\hline 122 & $28.70 \pm 3.11$ & Carra-2-1 & $49 \pm 2$ & 0.6 & 0.6 & 0.6 & $+0.1 /-0.1$ & $0.5-0.7$ & F2 \\
\hline 123 & $\begin{array}{l}160.21 \pm 12.8 \\
0\end{array}$ & $\begin{array}{l}\text { Carrascos } \\
-3\end{array}$ & $191 \pm 17$ & 0.9 & 0.8 & 0.8 & $+0.2 /-0.2$ & $0.7-1.1$ & F2 \\
\hline 124 & $109.72 \pm 5.88$ & G4 & 125-149 & 0.8 & 0.8 & 0.8 & $+0.2 /-0.1$ & $0.7-1.0$ & F2 \\
\hline 125 & $104.03 \pm 5.09$ & G3-G4 & $90-147$ & 0.9 & 0.8 & 0.9 & $+0.8 /-0.3$ & $0.6-1.7$ & $\begin{array}{l}\text { Sout } \\
h\end{array}$ \\
\hline 129 & $38.24 \pm 6.65$ & G3-G4 & $90-147$ & 0.4 & 0.3 & 0.3 & $+0.3 /-0.1$ & $0.3-0.7$ & F1 \\
\hline 136 & $68.83 \pm 11.68$ & $\begin{array}{l}\text { Carrascos } \\
-3\end{array}$ & $191 \pm 17$ & 0.4 & 0.4 & 0.4 & $+0.2 /-0.1$ & $0.3-0.6$ & F2b \\
\hline
\end{tabular}

Table 4. Lateral slip rates resulting from the combination of morphotectonic analysis and numerical dating in Goñar-Lorca segment of Alhama de Murcia fault. Channel 114 is measured remotely and in the field: second row of results (Fig. 6). The interpretation of each offset can be found in the supplementary material from S4-S12. Legend: depos. depositional. The calculations were done applying Zechar and Frankel (2009) functions.

\begin{tabular}{|c|c|c|}
\hline & Morphotectonic analyses & Paleoseismic trenches \\
\hline 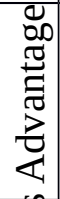 & $\begin{array}{l}\text { Suited where deformation affects several } \\
\text { sub-parallel fault strands }\end{array}$ & $\begin{array}{l}\text { Increased reliability in correlating offset } \\
\text { features (based on age, morphology and } \\
\text { facies) }\end{array}$ \\
\hline
\end{tabular}




\begin{tabular}{|c|c|c|}
\hline 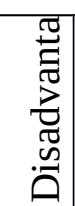 & $\begin{array}{l}\text { Reduced accuracy in channel age } \\
\text { determination. }\end{array}$ & $\begin{array}{l}\text { Unsuited where more than one strand is } \\
\text { present. }\end{array}$ \\
\hline
\end{tabular}

Table 5. Summary of the advantages and disadvantages of paleoseismic trenches and morphotectonic analyses in slip rate determination. 


\begin{tabular}{|c|c|c|c|c|c|c|c|c|c|c|c|c|c|c|}
\hline Sample Name & $\begin{array}{l}\mathrm{U} \\
\text { (ppb) }\end{array}$ & $\begin{array}{l}{ }^{232} \mathrm{Th} \\
\text { (ppb) }\end{array}$ & $\begin{array}{l}{ }^{230} \mathrm{Th} \\
\left.{ }^{232} \mathrm{Th}\right)\end{array}$ & $\begin{array}{l}\left({ }^{232} \mathrm{Th}\right. \\
\left.{ }^{238} \mathrm{U}\right)\end{array}$ & $\pm(\%)$ & $\begin{array}{l}\left({ }^{230} \mathrm{Th}\right. \\
\left.{ }^{238} \mathrm{U}\right)\end{array}$ & $\pm(\%)$ & $\begin{array}{l}{ }^{234} \mathrm{U} \\
\left.{ }^{238} \mathrm{U}\right)\end{array}$ & $\pm(\%)$ & \multicolumn{2}{|c|}{$\begin{array}{l}\text { Uncorrected Age, } \\
\text { Error } \\
(\mathrm{ka}, \pm \mathrm{ka})\end{array}$} & \multicolumn{2}{|c|}{$\begin{array}{ll}\text { Corrected } & \text { Age, } \\
\text { Error } & \\
(\mathrm{ka}, \pm \mathrm{ka}) & \end{array}$} & $\begin{array}{l}\text { Preferred U-Th Age for } \\
\text { Unit (ka, } \pm \text { ka) }\end{array}$ \\
\hline SALT13A16a & 4764 & 2794 & 1.052 & 0.19137 & 0.78 & 0.2014 & $\pm 2.3 \%$ & 0.789 & $\pm 3.4 \%$ & 32.6 & 0.70 & 8 & \pm 12 & \multirow{3}{*}{$\begin{array}{l}\mathrm{WM}(3)=12.39 \pm 0.42 ; \\
\text { prob. }=0.88\end{array}$} \\
\hline SALT13A16b & 8891 & 869.3 & 4.353 & 0.03201 & 3.07 & 0.1393 & $\pm 3.0 \%$ & 1.043 & $\pm 3.2 \%$ & 15.6 & 0.27 & 12.8 & \pm 1.4 & \\
\hline SALT13A16d & 7142 & 208.1 & 12.40 & 0.00954 & 0.45 & 0.1182 & $\pm 1.8 \%$ & 1.0379 & $\pm 0.51 \%$ & 13.2 & 0.20 & 12.35 & \pm 0.44 & \\
\hline SALT13B19a2 & 2720 & 709.5 & 2.93 & 0.08505 & 5.68 & 0.249 & $\pm 7.0 \%$ & 0.990 & $\pm 8.1 \%$ & 31.7 & 1.6 & 23.6 & \pm 5.0 & \multirow{6}{*}{$\begin{array}{l}\text { WM }(3 \text { oldest })=20.9 \\
\pm 2.5 ; \text { prob. }=0.62\end{array}$} \\
\hline SALT13B19b1 & 2946 & 1088 & 1.99 & 0.12082 & 4.21 & 0.241 & $\pm 6.4 \%$ & 1.084 & $\pm 4.4 \%$ & 27.3 & 3.2 & 16.8 & \pm 5.2 & \\
\hline SALT13B19b2 & 3337 & 903.4 & 2.91 & 0.08846 & 2.57 & 0.2572 & $\pm 3.0 \%$ & 1.100 & $\pm 3.1 \%$ & 28.9 & 1.9 & 21.5 & \pm 3.5 & \\
\hline SALT13B19b3 & 2141 & 772.0 & 1.908 & 0.11802 & 1.96 & 0.2252 & $\pm 2.9 \%$ & 1.039 & $\pm 2.9 \%$ & 26.6 & 0.46 & 15.9 & \pm 4.9 & \\
\hline SALT13B19c & 14652 & 390.3 & 11.518 & 0.00869 & 0.37 & 0.10004 & $\pm 0.82 \%$ & 1.0590 & $\pm 0.23 \%$ & 10.8 & 0.07 & 10.07 & \pm 0.33 & \\
\hline SALT13B19d & 6474 & 608.3 & 4.31 & 0.03079 & 6.36 & 0.133 & $\pm 13 \%$ & 0.99 & $\pm 16 \%$ & 15.8 & 1.4 & 12.9 & \pm 3.3 & \\
\hline SALT5CANa & 4933 & 673.9 & 3.027 & 0.04471 & 0.68 & 0.1353 & $\pm 1.3 \%$ & 1.0543 & $\pm 0.84 \%$ & 15.0 & 0.11 & 11.1 & \pm 1.7 & \multirow{4}{*}{$\begin{array}{l}\text { WM }(3 \text { oldest })=11.0 \\
\pm 1.7 ; \text { prob. }=0.97\end{array}$} \\
\hline SALT5CANb & 2049 & 1229 & 1.174 & 0.19526 & 6.46 & 0.229 & $\pm 7.5 \%$ & 1.00 & $\pm 10 \%$ & 28.4 & 1.8 & 9.2 & \pm 9.4 & \\
\hline SALT5CANc & 2721 & 685.2 & 1.664 & 0.08229 & 5.35 & 0.1370 & $\pm 3.4 \%$ & 1.134 & $\pm 7.2 \%$ & 14.0 & 1.5 & 7.3 & \pm 3.1 & \\
\hline SALT5CANd & 2121 & 2164 & 1.095 & 0.33394 & 0.98 & 0.3657 & $\pm 1.6 \%$ & 1.037 & $\pm 1.8 \%$ & 47.3 & 2.0 & 14 & \pm 17 & \\
\hline CARR4 a1 & 1003 & 569.5 & 1.872 & 0.18651 & 0.56 & 0.3491 & $\pm 2.8 \%$ & 1.159 & $\pm 6.6 \%$ & 38.8 & 4.3 & 23.4 & \pm 7.3 & \multirow{5}{*}{$\begin{array}{l}\text { WM }(3 \text { oldest })=23.2 \\
\pm 4.2 ; \text { prob. }=0.95\end{array}$} \\
\hline CARR4 b1 & 1169 & 900.7 & 1.220 & 0.25167 & 4.22 & 0.307 & $\pm 3.8 \%$ & 1.22 & $\pm 8.8 \%$ & 31.3 & 4.5 & 11.2 & \pm 9.5 & \\
\hline CARR4 b2 & 1058 & 505.1 & 1.931 & 0.15617 & 0.97 & 0.302 & $\pm 4.4 \%$ & 1.077 & $\pm 2.6 \%$ & 35.7 & 1.0 & 21.8 & \pm 6.6 & \\
\hline CARR4 c & 1030 & 676.7 & 1.713 & 0.21585 & 0.53 & 0.3697 & $\pm 2.4 \%$ & 1.095 & $\pm 3.6 \%$ & 44.6 & 1.2 & 25.4 & \pm 9.0 & \\
\hline CARR4 d & 1178 & 654.1 & 1.47 & 0.18228 & 6.29 & 0.268 & $\pm 9.5 \%$ & 1.46 & $\pm 25 \%$ & 21.9 & 4.4 & 10.2 & \pm 6.3 & \\
\hline LiM4 a1 & 1803 & 477.3 & 1.811 & 0.08690 & 0.72 & 0.157 & $\pm 9.2 \%$ & 1.041 & $\pm 2.0 \%$ & 17.8 & 1.5 & 10.1 & \pm 3.9 & \multirow{5}{*}{$\begin{array}{l}\text { WM }(3 \text { oldest })=11.7 \\
\pm 2.6 ; \quad \text { prob. }=0.84\end{array}$} \\
\hline LiM4 a2 & 1732 & 507.2 & 1.723 & 0.09578 & 0.22 & 0.1650 & $\pm 2.5 \%$ & 1.072 & $\pm 1.5 \%$ & 18.2 & 0.28 & 9.9 & \pm 3.7 & \\
\hline LiM4 b & 1183 & 458.4 & 1.667 & 0.12664 & 0.89 & 0.211 & $\pm 6.1 \%$ & 1.043 & $\pm 5.9 \%$ & 24.6 & 3.2 & 13.1 & \pm 5.5 & \\
\hline LiM4 c & 1050 & 492.8 & 1.267 & 0.15406 & 0.45 & 0.195 & $\pm 5.8 \%$ & 1.068 & $\pm 5.5 \%$ & 22.0 & 2.6 & 8.2 & \pm 6.4 & \\
\hline LiM4 d & 1006 & 335.7 & 1.817 & 0.10921 & 1.77 & 0.198 & $\pm 6.3 \%$ & 1.035 & $\pm 5.6 \%$ & 23.2 & 0.82 & 13.2 & \pm 4.8 & \\
\hline LIMII5 b1 & 1679 & 649.7 & 3.382 & 0.12654 & 2.65 & 0.428 & $\pm 2.4 \%$ & 1.072 & $\pm 4.1 \%$ & 55.2 & 1.8 & 44.1 & \pm 5.9 & \\
\hline
\end{tabular}




\begin{tabular}{|c|c|c|c|c|c|c|c|c|c|c|c|c|c|c|}
\hline LIMII5 b2 & 1849 & 786.2 & 3.242 & 0.13972 & 1.46 & 0.4529 & $\pm 1.9 \%$ & 1.022 & $\pm 2.1 \%$ & 63.7 & 0.97 & 50.7 & \pm 6.5 & \multirow{3}{*}{$\begin{array}{l}\text { WM }(3 \text { oldest })=46.6 \\
\pm 5.7 ; \quad \text { prob. }=0.75\end{array}$} \\
\hline LIMII5 c & 1752 & 450.4 & 4.757 & 0.08409 & 1.20 & 0.4000 & $\pm 2.3 \%$ & 1.0244 & $\pm 0.85 \%$ & 53.9 & 1.1 & 46.2 & \pm 3.9 & \\
\hline LIMII5 d & 1560 & 547.8 & 3.37 & 0.11479 & 6.12 & 0.386 & $\pm 4.5 \%$ & 0.989 & $\pm 3.7 \%$ & 54.0 & 1.3 & 43.0 & \pm 6.5 & \\
\hline PERA a & 1719 & 957.1 & 1.498 & 0.18246 & 0.53 & 0.2733 & $\pm 2.7 \%$ & 0.965 & $\pm 3.4 \%$ & 36.4 & 0.78 & 17.8 & \pm 8.9 & \multirow{5}{*}{$\begin{array}{l}\text { WM }(3 \text { oldest })=23.8 \\
\pm 3.2 ; \text { prob. }=0.76\end{array}$} \\
\hline PERA b1 & 1407 & 478.4 & 2.441 & 0.11080 & 1.10 & 0.2704 & $\pm 1.7 \%$ & 0.987 & $\pm 1.4 \%$ & 35.0 & 1.21 & 24.3 & \pm 4.9 & \\
\hline PERA b2 & 1350 & 594.1 & 1.43 & 0.14354 & 3.23 & 0.205 & $\pm 39 \%$ & 1.042 & $\pm 5.7 \%$ & 23.8 & 12 & 11 & \pm 12 & \\
\hline PERA C & 1138 & 368.4 & 2.595 & 0.10585 & 2.29 & 0.2747 & $\pm 2.3 \%$ & 0.995 & $\pm 4.5 \%$ & 35.2 & 1.2 & 25.2 & \pm 4.9 & \\
\hline PERA d & 1387 & 381.4 & 2.259 & 0.08993 & 1.36 & 0.203 & $\pm 5.5 \%$ & 0.974 & $\pm 2.7 \%$ & 25.5 & 2.3 & 16.9 & \pm 4.2 & \\
\hline LIM II7a1 & 764 & 360.8 & 4.64 & 0.15450 & 0.20 & 0.717 & $\pm 2.8 \%$ & 1.0519 & $\pm 0.18 \%$ & 123.1 & \pm 6.3 & 109.3 & \pm 9.7 & \multirow{5}{*}{$\begin{array}{lrr}\text { WM } \quad(3 & \text { oldest })= \\
105.1 \pm 4.2 ; & \text { prob. }= \\
0.12 & \end{array}$} \\
\hline LIM II7a2 & 730 & 250.1 & 6.45 & 0.11210 & 0.16 & 0.723 & $\pm 2.2 \%$ & 1.0506 & $\pm 0.20 \%$ & 125.4 & \pm 5.2 & 115.5 & \pm 7.4 & \\
\hline LIM II7c & 999 & 447.8 & 4.55 & 0.14634 & 0.17 & 0.666 & $\pm 2.5 \%$ & 1.0527 & $\pm 0.26 \%$ & 108.0 & \pm 4.6 & 94.9 & \pm 8.0 & \\
\hline LIM II7d & 838 & 314.1 & 5.384 & 0.12260 & 0.17 & 0.6601 & $\pm 1.3 \%$ & 1.0470 & $\pm 0.14 \%$ & 107.4 & \pm 2.5 & 96.5 & \pm 6.0 & \\
\hline LIM II7e & 803 & 382.1 & 4.24 & 0.15541 & 0.20 & 0.658 & $\pm 2.7 \%$ & 1.0806 & $\pm 0.25 \%$ & 100.8 & \pm 4.5 & 87.4 & \pm 7.9 & \\
\hline
\end{tabular}

Table 2. U-Th isotopic data and ages for pedogenic carbonate. All isotope ratios are activity ratios. Uncertainties are given at 1 standard deviation. Uncorrected ages are calculated without correction for $U$ and Th from detritus. Corrected ages are calculated assuming detritus with $\left({ }^{232} \mathrm{Th} /{ }^{238} \mathrm{U}\right)=1.2 \pm 0.6,\left({ }^{230} \mathrm{Th} /{ }^{238} \mathrm{U}\right)=1.0 \pm 0.1$, and $\left({ }^{234} \mathrm{U} /{ }^{238} \mathrm{U}\right)=1.0 \pm 0.1$. Decay constants are those of Jaffey (1971) for ${ }^{238} \mathrm{U}$ and Cheng et al. (2013) for ${ }^{230} \mathrm{Th}$ and ${ }^{234} \mathrm{U}$. WM $(\mathrm{N})=$ weighted mean, where $\mathrm{N}=$ no. of samples; prob. is the probability that the observed scatter is due to analytical errors. Sub-samples from different clast are indicated with letters (a to d) and sub-samples from the same clast, with numbers (1-3). 


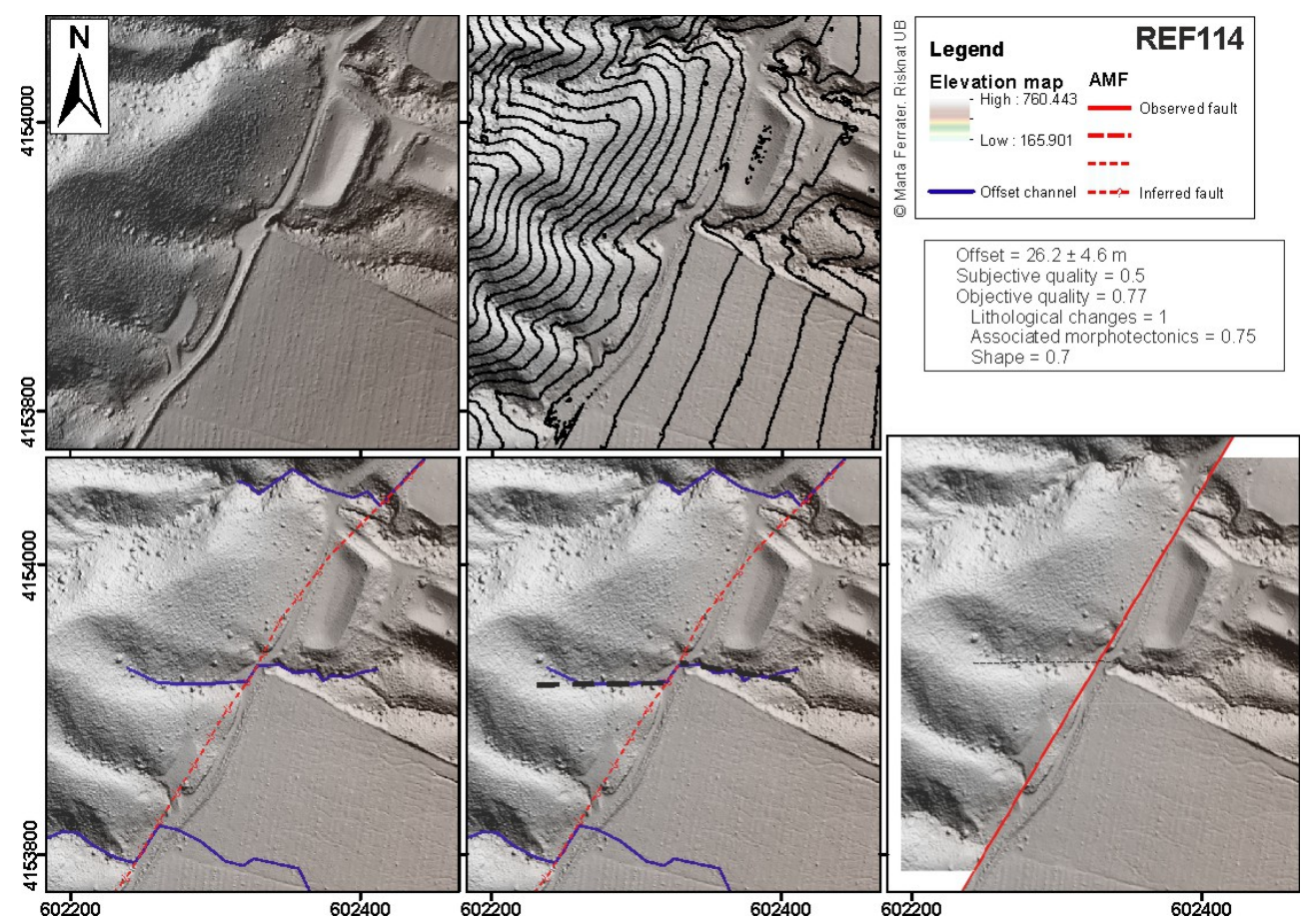

Figure S1. Interpretation of offset 114: A) $0.5 \times 0.5 \mathrm{~m}$ pixel size Digital Elevation Model (DEM) hillshade; (B) $0.5 \times 0.5 \mathrm{~m}$ pixel size DEM hillshade and $5 \mathrm{~m}$ contour map; (C) $0.5 \times 0.5 \mathrm{~m}$ pixel size DEM hillshade showing the location of the fault and the offset stream; (D) $0.5 \times 0.5 \mathrm{~m}$ pixel size DEM hillshade showing some projected piercing lines (black dashed lines); and (E) back slip model of the offset. Offset in meters.

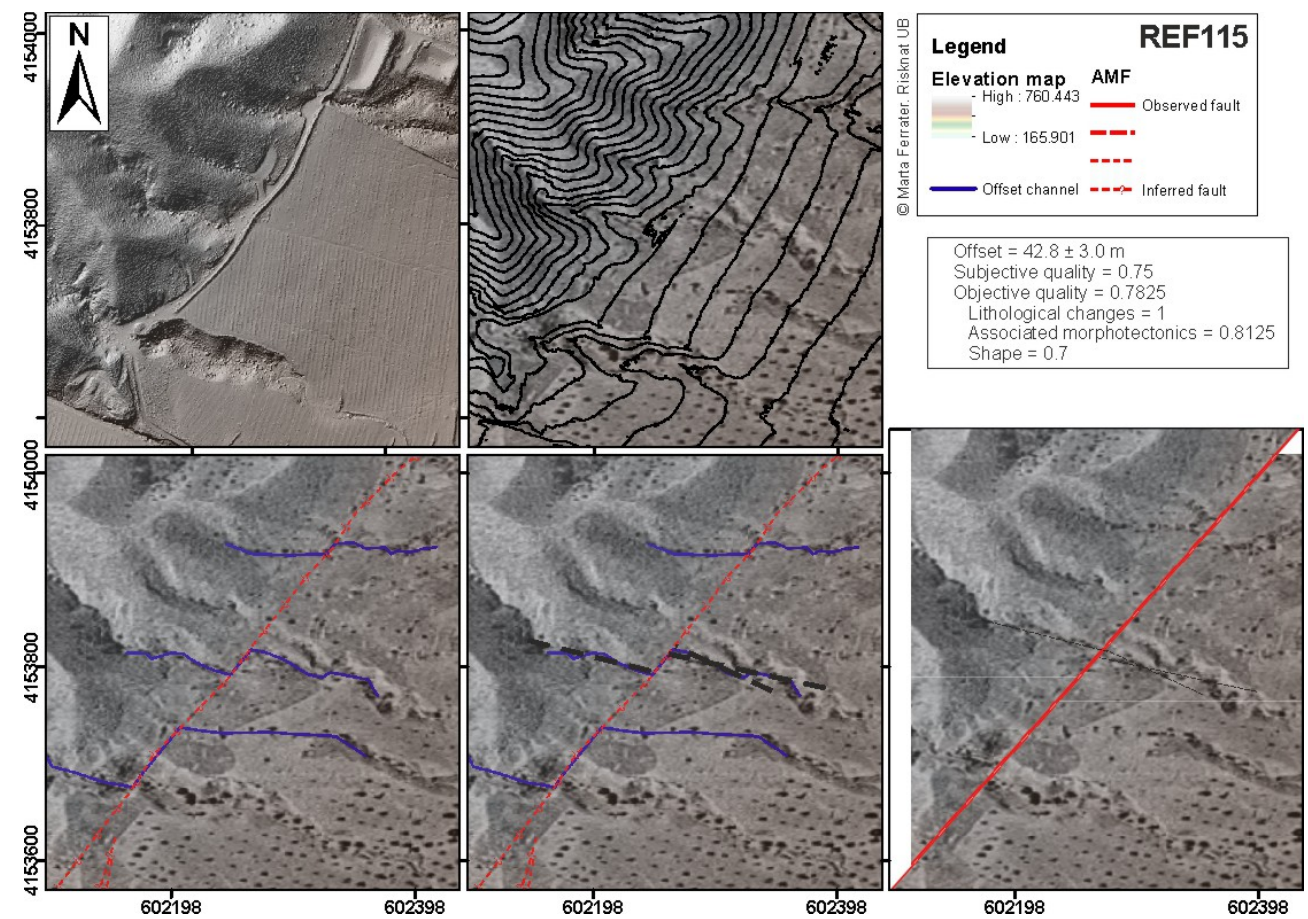

Figure S2. Interpretation of offset 115: A) $0.5 \times 0.5 \mathrm{~m}$ pixel size Digital Elevation Model (DEM) hillshade; (B) 1956 ortophoto and 5 m contour map; (C) 1956 ortophoto showing the location of the fault and the offset stream; (D) 1956 ortophoto showing 
some projected piercing lines (black dashed lines); and (E) back slip model of the offset. Offset in meters.

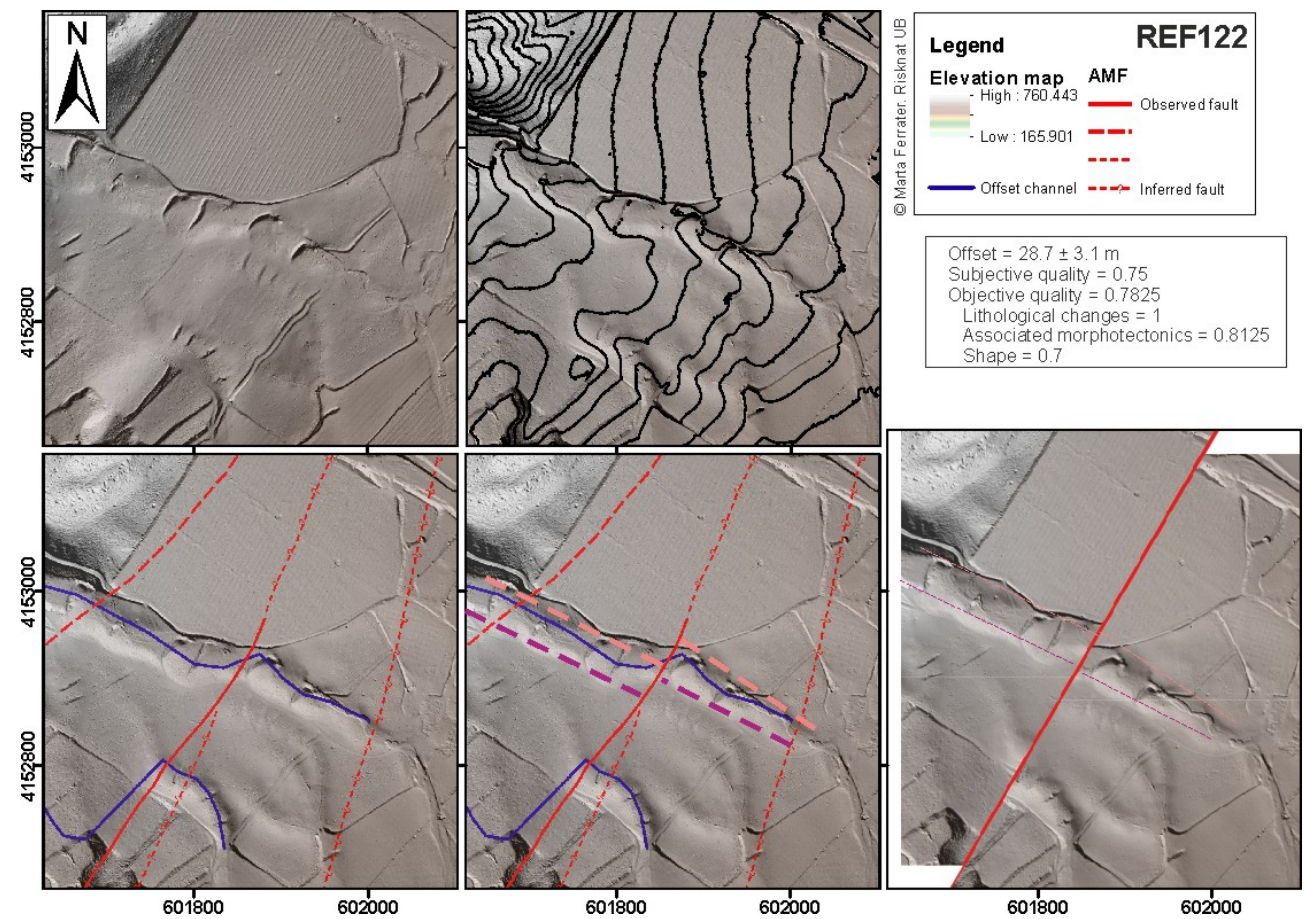

Figure S3. Interpretation of offset 122: A) $0.5 \times 0.5 \mathrm{~m}$ pixel size Digital Elevation Model (DEM) hillshade; (B) $0.5 \times 0.5 \mathrm{~m}$ pixel size DEM hillshade and $5 \mathrm{~m}$ contour map; (C) $0.5 \times 0.5 \mathrm{~m}$ pixel size DEM hillshade showing the location of the fault and the offset stream; (D) $0.5 \times 0.5 \mathrm{~m}$ pixel size DEM hillshade showing some projected piercing lines (pink dashed lines represent the left bank of the channel, and purple lines the right bank looking downstream); and (E) back slip model of the offset. Offset in meters.

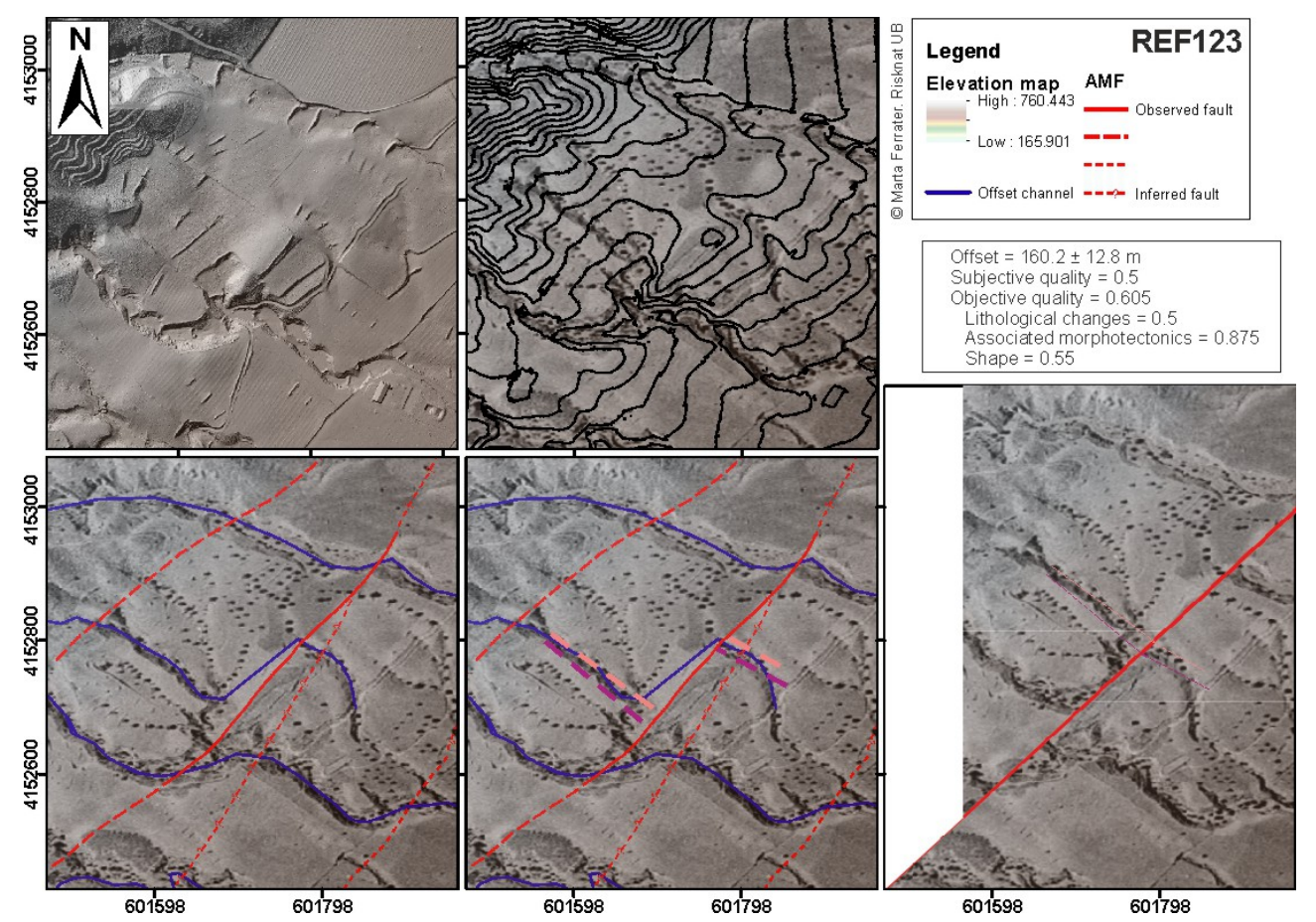


Figure S4. Interpretation of offset 123: A) $0.5 \times 0.5 \mathrm{~m}$ pixel size Digital Elevation Model (DEM) hillshade; (B) 1956 ortophoto and 5 m contour map; (C) 1956 ortophoto showing the location of the fault and the offset stream; (D) 1956 ortophoto showing some projected piercing lines (pink dashed lines represent the left bank of the channel, and purple lines the right bank looking downstream); and (E) back slip model of the offset. Offset in meters.

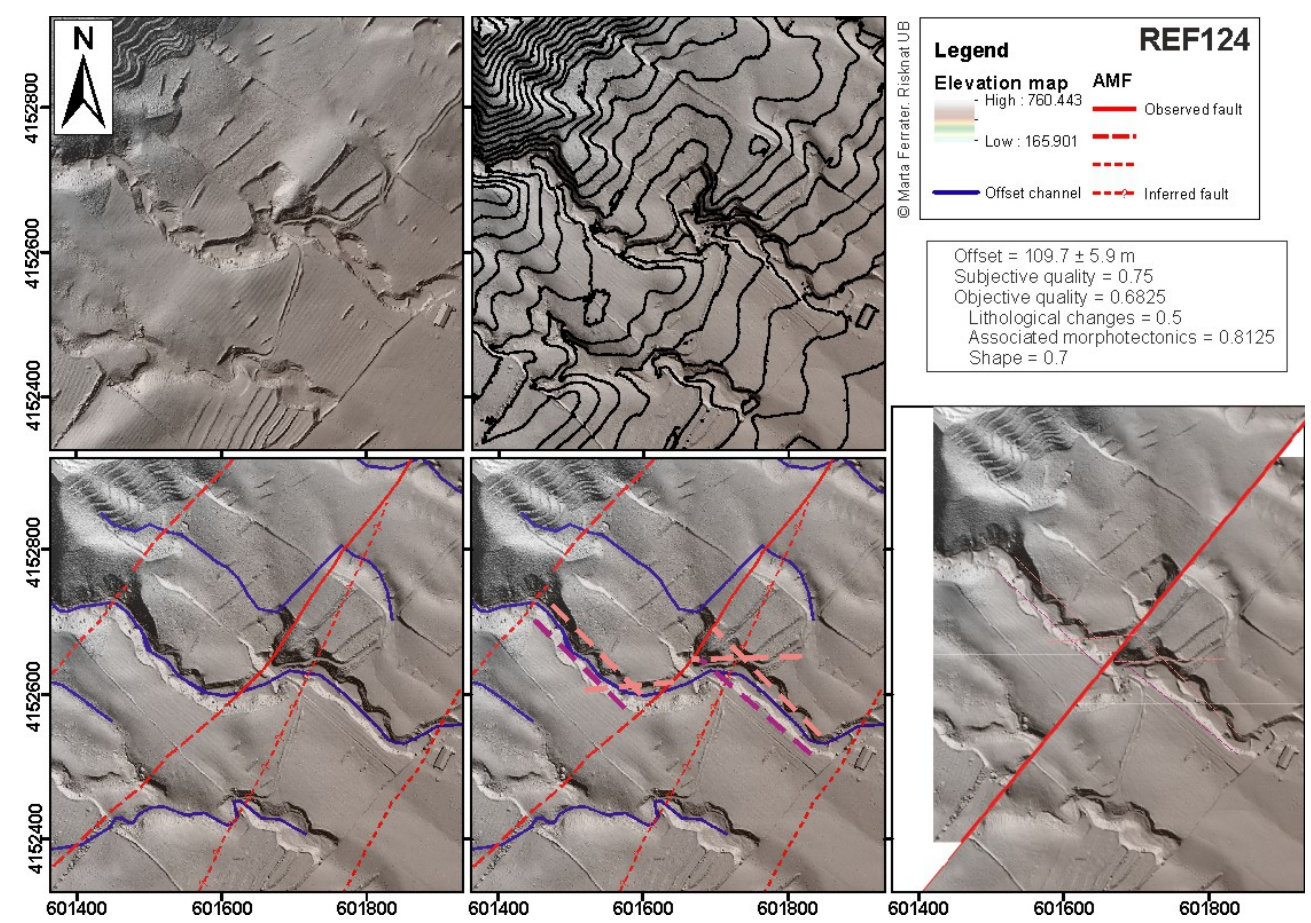

Figure S5. Interpretation of offset 124: A) $0.5 \times 0.5 \mathrm{~m}$ pixel size Digital Elevation Model (DEM) hillshade; (B) $0.5 \times 0.5 \mathrm{~m}$ pixel size DEM hillshade and $5 \mathrm{~m}$ contour map; (C) $0.5 \times 0.5 \mathrm{~m}$ pixel size DEM hillshade showing the location of the fault and the offset stream; (D) $0.5 \times 0.5 \mathrm{~m}$ pixel size DEM hillshade showing some projected piercing lines (pink dashed lines represent the left bank of the channel, and purple lines the right bank looking downstream); and (E) back slip model of the offset. Offset in meters. 

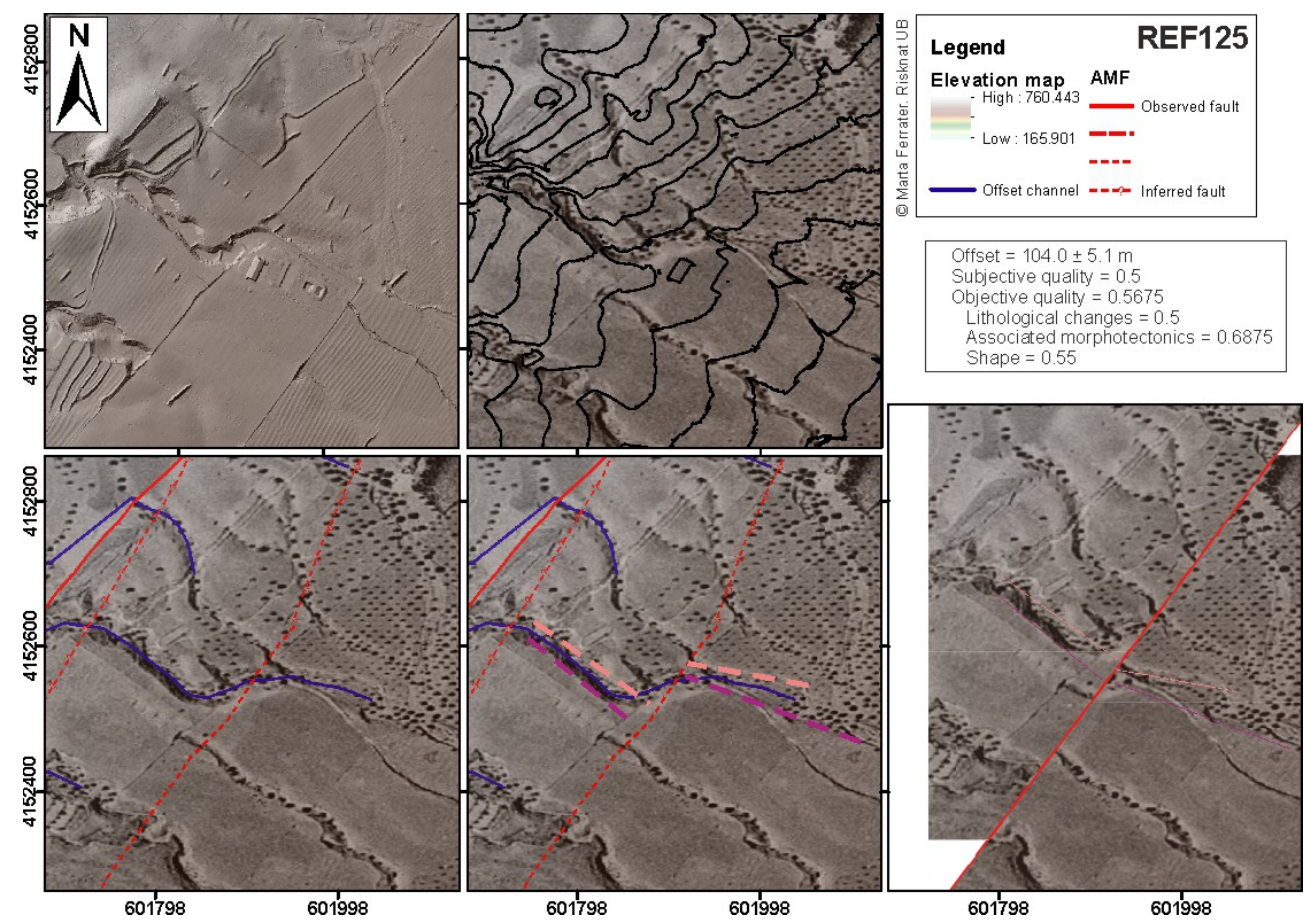

Figure S6. Interpretation of offset 125: A) $0.5 \times 0.5 \mathrm{~m}$ pixel size Digital Elevation Model (DEM) hillshade; (B) 1956 ortophoto and 5 m contour map; (C) 1956 ortophoto showing the location of the fault and the offset stream; (D) 1956 ortophoto showing some projected piercing lines (pink dashed lines represent the left bank of the channel, and purple lines the right bank looking downstream); and (E) back slip model of the offset. Offset in meters.

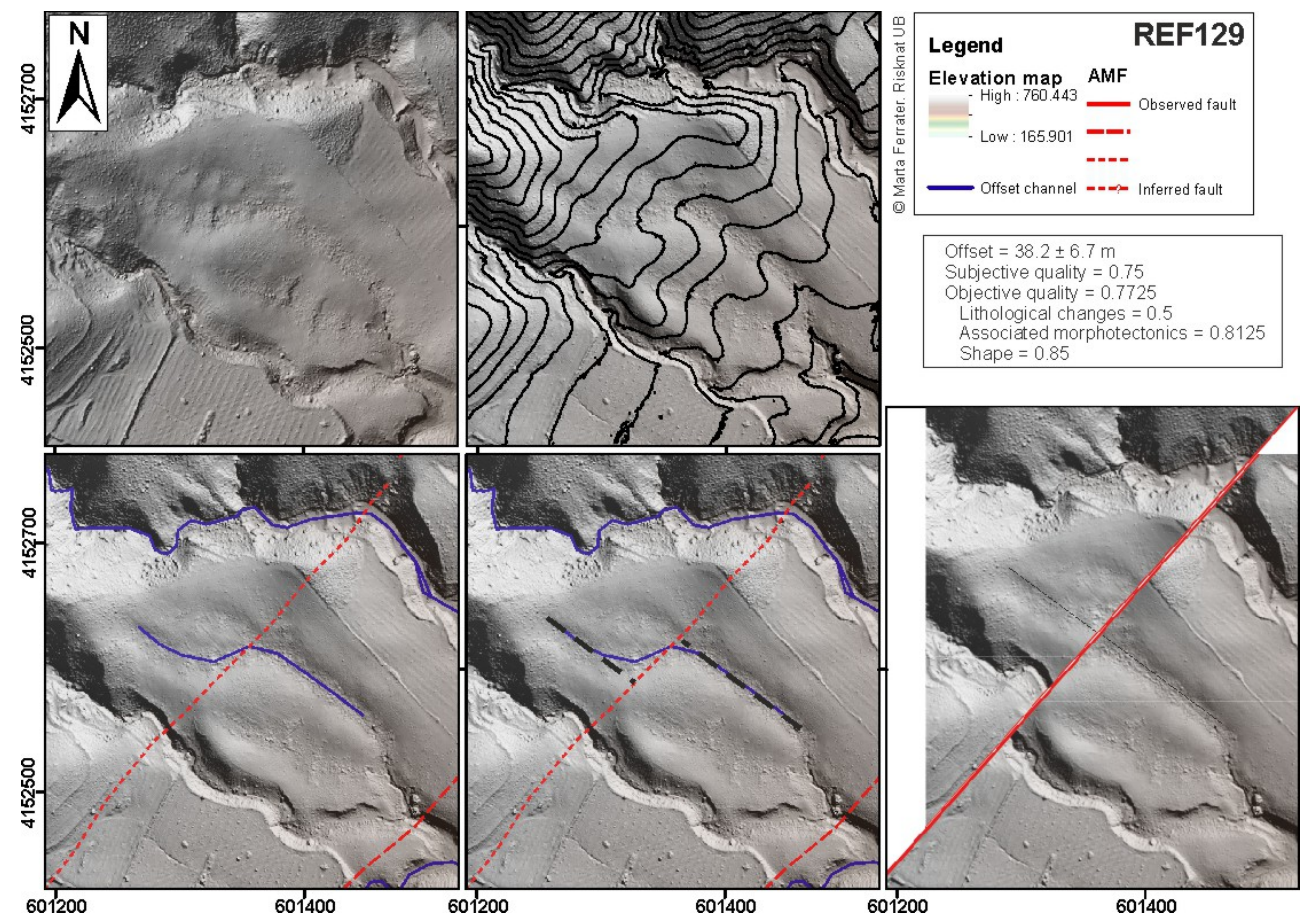

Figure S7. Interpretation of offset 129: A) $0.5 \times 0.5 \mathrm{~m}$ pixel size Digital Elevation Model (DEM) hillshade; (B) $0.5 \times 0.5 \mathrm{~m}$ pixel size DEM hillshade and $5 \mathrm{~m}$ contour map; (C) $0.5 \times 0.5 \mathrm{~m}$ pixel size DEM hillshade showing the location of the fault and the 
offset stream; (D) $0.5 \times 0.5 \mathrm{~m}$ pixel size DEM hillshade showing some projected piercing lines (black dashed lines); and (E) back slip model of the offset. Offset in meters.

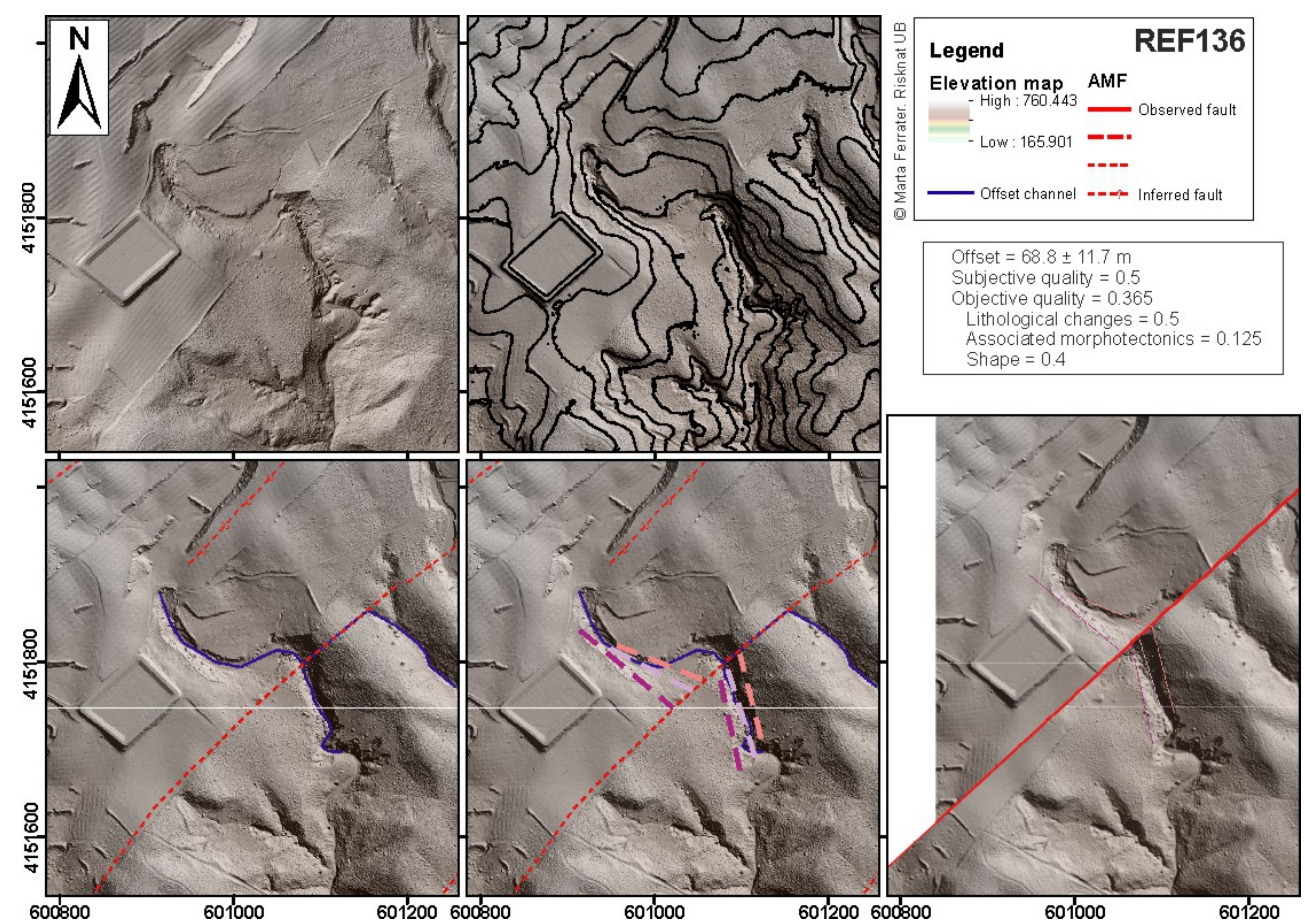

Figure S8. Interpretation of offset 136: A) $0.5 \times 0.5 \mathrm{~m}$ pixel size Digital Elevation Model (DEM) hillshade; (B) $0.5 \times 0.5 \mathrm{~m}$ pixel size DEM hillshade and $5 \mathrm{~m}$ contour map; (C) $0.5 \times 0.5 \mathrm{~m}$ pixel size DEM hillshade showing the location of the fault and the offset stream; (D) $0.5 \times 0.5 \mathrm{~m}$ pixel size DEM hillshade showing some projected piercing lines (pink dashed lines represent the left bank of the channel, and purple lines the right bank looking downstream); and (E) back slip model of the offset. Offset in meters. 